\title{
Testing integrated electric vehicle charging and domestic heating strategies for future UK housing
}

\author{
Nick Kelly*, Aizaz Samuel, John Hand \\ Energy Systems Research Unit (ESRU), Department of Mechanical and Aerospace \\ Engineering, University of Strathclyde, Glasgow, UK \\ *Corresponding Author \\ e-mail: nick@esru.strath.ac.uk; tel: +44141 574 5083; fax: +44141 5525105
}

\begin{abstract}
A building simulation tool and customised electric vehicle (EV) charging algorithm was used to investigate the impact of electrified home heating coupled with $\mathrm{EV}$ charging on the electrical demand characteristics of a future, net-zero-energy UK dwelling. A range of strategies by which EV charging and electrified heating could be controlled in order to minimise household peak demands were tested including off-peak load shifting, fast and slow vehicle charging, demand limited charging and heating, and bi-directional battery operation. The simulation results indicate that in all cases, electrical energy use was more than doubled compared to a base case with no EV or electric heating. The peak demand also increased substantially. The most effective strategy to limit peak demand, whilst also minimising the impact on end user comfort and EV availability, was to control the heat pump operation and vehicle charging using a demand limit, this restricted the rise in absolute peak demand to $46 \%$ above that of the base case. Off-peak load shifting proved ineffective at reducing absolute peak demands and resulted in increased discomfort in the house. Peak limiting of EV charging proved a more useful load management mechanism than allowing the vehicle battery to discharge.
\end{abstract}

Keywords: electric vehicle, heat pump, zero energy dwelling, electrical demand, simulation

\section{NOMENCLATURE}

$d$ - distance $(\mathrm{km})$

$D$ - battery discharge $\mathrm{kWh} / \mathrm{km}$

$F$ - cumulative probability (0-1)

$k-$ Wiebull distribution parameter (-)

$L$ - parasitic discharge $\mathrm{kWh} / \mathrm{km}$

$n$ - number of legs on a trip

$p$ - probability (-)

$P$ - power demand $(\mathrm{W})$

$v$ - velocity $(\mathrm{km} / \mathrm{hr})$

$x, y, z$ - random numbers (-)

6 Subscripts

$37 h$-hourly 
$H$ - household

$M A X-$ maximum

$M I N$ - minimum

$$
O P \text { - START/END - off peak tariff start/end time (hours) }
$$

\section{Greek Symbols}

$\Delta t$ - time interval (seconds)

\section{$\lambda$ - Weibull distribution parameter (-)}

\section{INTRODUCTION}

The coming decades will herald a substantial change in the thermal and electrical demand of new and refurbished dwellings, brought about by a combination of improved thermal insulation and air tightness, the increased integration of microgeneration technologies such as $\mathrm{PV}$, the possible electrification of heating through the use of heat pumps and the homecharging of part-or-all-electric vehicles (EV). Together, these changes would result in UK household demand characteristics being radically different from those seen today, where space heating dominate (Palmer and Cooper, 2012).

Improved thermal performance in both new build and retrofit housing would reduce the predominance of domestic space heating, placing more of a focus on the electrical and hot water demands. At present, in a typical UK dwelling, space heating accounts for around $65 \%$ of overall energy demand (Palmer and Cooper, 2012), whilst in better insulated and sealed Passive House designs, space heating can be reduced by upwards of $80 \%$ (Schneiders, 2003). The trend towards reduced space heating in UK dwellings is occurring now, with total household space heating demand declining by $21 \%$ since 2004 - driven by more stringent building regulations along with higher energy costs and government incentives encouraging domestic fabric improvements (Palmer and Cooper, 2012). Conversely, total household electrical demand has increased by approximately $15 \%$ over the same period (Palmer and Cooper, 2012) - driven by increasing numbers of appliances and behavioural changes such as increasing use of home entertainment devices and the advent of 'always on' devices such as broadband routers.

In tandem with changes in domestic energy demand, the supply of energy to UK dwellings is also undergoing a transformation, through the provision of thermal and electrical energy from local, low-carbon sources. For example, more than $2 \mathrm{GW}$ of microgeneration capacity has been installed in the UK since the introduction of a feed-in-tariff (FIT) in 2010 (OFGEM, 2013). This provides small scale producers (i.e. householders) with a guaranteed payment for each kWh of electricity produced by a household renewable source such as photovoltaic panels (PV).

For the UK is to achieve its ambitious target of an $80 \%$ greenhouse gas emissions reduction by 2050 , relative to 1990 baseline, then the use of fossil fuels in domestic heating will need to be virtually eliminated (DECC, 2008) and replaced with zero carbon energy sources such as biomass, which realistically could only supply a fraction of heat demand (Castillo and Panoutsou, 2011), and renewable electricity. The latter requires the widespread uptake of heat pumps that shift the heating load from the natural gas to the electricity network. As the majority of current UK dwellings will still exist in 2050, (Hinnels et al, 2007) then a widespread heat pump retrofit programme would be required to bring about this shift. Air source heat pumps (ASHPs) have the potential to act as a replacement for the fossil-fuelled boilers most commonly found in UK housing. Additionally, their relatively low cost of 
installation and the lack of a requirement for ground works makes ASHPs a more feasible mass retrofit option than ground source heat pumps (GSHP). However, Wilson et al (2013) indicated that a shift of only $30 \%$ of domestic heating to heat pumps could result in an increase in the total UK electrical demand of some $25 \%$.

The final development likely to have a significant impact on the characteristics of domestic demand is the growth in the use of electric vehicles (EVs). In the UK, the number of electric vehicles is still small as a percentage of the total fleet - some $0.1 \%$ of the total passenger cars licenced on UK roads (DfT, 2014). However, their number is increasing exponentially. EVs shift the energy used for transportation from refined fossil fuels to the electricity network. In the UK, the domestic sector accounts for around $29 \%$ of UK final energy consumption, whilst the transport sector accounts for another 36\% of demand (DECC, 2012). The deployment of EVs at an increasing rate and the widespread electrification of domestic heating could lead to a massive rise in the demand for electricity and necessitate the upgrading of the UK's electricity distribution infrastructure. In this paper, the potential increase in electricity demand at the individual dwelling level is examined along with an investigation into the strategies that could be employed to mitigate the worst effects of this increase.

\subsection{Previous Work on Domestic Electrification}

Many previous papers have analysed the thermal performance of future buildings (e.g. Attia et al, 2013), microgeneration and the electrification of heat (e.g. Wilson et al, 2013), and the potential impact of EVs on the electrical network (e.g. Pudjianto et al, 2013). However, there is a paucity of material looking specifically at the combinatorial effects of heat pumps and EVs on future domestic energy demands, and strategies to mitigate their impact - typically, studies treat the two topics separately. There are some examples in the literature that look at the integrated control of EV charging within a domestic context in order to mitigate demand peaks, but the majority of work focuses on the charging of many vehicles at the communuty (or larger) scale. Robinson et al (2013) analysed the results from a large UK field trail of electric vehicles, where the charging times of vehicles were unconstrained and vehicles could be charged at home or when parked away from home. Their results indicated a significant amount of peak-time charging. Razeghi et al (2014) used real US domestic electricity demand data coupled with stochastic vehicle charging profiles to look at the potential impact of EV charging on distribution transformers. The authors concluded that only in the case of uncontrolled fast charging of vehicles would there be the risk of transformer overloading. The study did not include heat pumps. In a study using economic optimisation, Hedegaard et al (2012) looked at the possible impact of EV charging in Northern European countries, indicating that coordinated charging of EV's can boost investment in wind power and reduce future investment requirements for thermal power plants. However, the study did not look at the implications for the transmission and generation infrastructure.

Of the studies looking at both the dwelling and EV, Asare-Bediako et al (2014) looked at the potential effect of heat electrification using micro-CHP and electric vehicles on domestic load profiles in the Netherlands using a bottom-up modelling approach. The authors concluded that the electrical load profile characteristics changed dramatically with reduced electrical peak demand in summer and increased demand in winter. The authors did not investigate the possibility of co-operation between the house and vehicle to limit peak demand, nor did they address the issue of heat pumps. Munkhammar et al (2013) used a stochastic, high-resolution model to examine the impact of EVs on domestic load and the self-consumption of PVgenerated power in Swedish housing. Their paper highlighted the increase in domestic power consumption with the introduction of EVs and also noted that in many cases the use of EVs decreased the amount of load covered by the PV. This was due to the temporal mismatch 
131 between when PV power was available and when the EV charged (typically early morning or evening). Haines et al (2009) looked at the so-called vehicle-to-home concept (V2H), using the vehicle battery to co-operatively limit the peak demand of a UK household. The authors concluded that EVs could be used to limit peak demand and improve domestic load factors, other than in cases where the EV was used for a sizable commute. However, the study did not consider electrification of heating.

\subsection{Scope of the paper}

138 In the literature, the impact of wholesale domestic electrification (extending to heating and transportation) is rarely considered, and by extension, most mitigation strategies focus on only one aspect of demand. Consequently, this paper explores a range of strategies aimed at limiting the impact of both heat pumps and EVs on the electrical demand of future dwellings. The paper examines the peak electrical demand and the increase in household electrical energy use as both will have an impact on electrical infrastructure. Increased electrical energy use will lead to higher temperatures in electrical equipment and ultimately a shortening of its lifespan. However, a radical increase in peak demand could have the most acute impact, necessitating the wholesale replacement of electrical infrastructure such as cabling and electrical transformers.

A simulation model of a hypothetical future zero-energy dwelling (described later) was used as a virtual test bed to analyse the electrical demand of the household, accounting for electrified space heating, hot water demand, appliance and home charging of vehicles. The simulation model also allowed the impact of demand management measures on other aspects of performance to be investigated - specifically the impact of heat pump demand management of the thermal performance of the dwelling and the impact of vehicle charging load management on the availability of the EV. The range of electrical demand strategies investigated using this model was as follows.

- Time-shifting of heating: where the operation of a heat pump was moved to periods of off-peak electrical demand $(11 \mathrm{pm}-7 \mathrm{am})$. This required that the heat pump was coupled to the heating system of the dwelling via a buffer tank.

- Peak limited heating: the operation of the heat pump was halted if the total household demand exceeded $7.5 \mathrm{~kW}^{1}$.

- Fast and slow battery charging: charging rates of 3.3 and $6.6 \mathrm{~kW}$ were tested.

- Time shifting of battery charging: battery charging was restricted to periods of offpeak electrical demand.

- Peak limited battery charging: the battery was only charged when the load of the dwelling fell below $7.5 \mathrm{~kW}$.

- Bi-directional battery operation: the battery was charged or discharged in order to limit the building demand at $7.5 \mathrm{~kW}$.

168 Later, these individual strategies were combined into a set of modelled scenarios, which explored increasing levels of demand intervention in both vehicle charging and heating use.

\footnotetext{
1 IEA EBC Annex 42 measured data (IEA, 2014) was reviewed to determine a typical dwelling maximum electrical demand limit for many of the scenarios above; this data shows maximum demand in UK-housing varying between 3.5 and $7.5 \mathrm{~kW}$. In order to mitigate the effects of vehicle charging and electric heating on the existing electrical infrastructure it would be necessary to keep overall demand below these peaks. Consequently, the upper demand value of $7.5 \mathrm{~kW}$ was used in this paper in the control of heating and vehicle charging. However, the impact of varying the demand limit merits further investigation.
} 


\section{MODELLING HOUSEHOLD ELECTRICAL DEMAND}

Hawkes and Leach (2005) and Knight and Ribberink (2007) argue that to properly capture the electrical demand characteristics and the exchange of electrical power between a dwelling and the grid, simulation time steps of less than 10 minutes are required. Consequently, to fully assess the impact of vehicle charging and the electrification of heating, the ESP-r building simulation tool (ESRU, 2014), used as the modelling engine in this paper, has been upgraded to enable it to work at 1-minute resolution and to simulate vehicle battery-charging loads. Further, a hypothetical zero-energy dwelling simulation model has been developed (Hand et al, 2014), complete with an EV.

ESP-r, allows the energy and environmental performance of the building and its energy systems to be determined over a user defined time interval (e.g a day, week, year). The tool explicitly calculates all of the energy and mass transfer processes underpinning building performance. These include conduction and thermal storage in building materials, all convective and radiant heat exchanges (including solar processes and long wave exchange with the sky), air flows and interaction with plant and control systems. To achieve this, a physical description of the building (materials constructions, geometry, etc.) is decomposed into thousands of "control volumes". In this context, a control volume is an arbitrary region of space to which conservation equations for continuity, energy (thermal and electrical) and species can be applied and one or more characteristic equations formed. A typical building model will contain thousands of such volumes, with sets of equations extracted and grouped according to energy system. The solution of these equations sets with real, time-series climate data, coupled with control and occupancy-related boundary conditions yields the dynamic evolution of temperatures, energy exchanges (heat and electrical) and fluid flows within the building and its supporting systems. An exhaustive description of the theoretical basis of ESP-r is provided by Clarke (2001).

\subsection{Adaptations to ESP-r}

The ESP-r software has been extended from the standard release to enable its electrical systems algorithm (Kelly, 1998) to use stochastic, electrical appliance demand data as a boundary condition. This data was generated at a 1-minute time resolution using a customised version of a domestic appliance demand profile tool (Richardson et al, 2010), which also produced matching thermal gains profiles. Additionally, a new algorithm was developed, based on the work of Jordan and Vagen (2005), which enabled stochastic, sub-hourly resolution domestic hot water draws to be generated during a simulation. Finally, using the work of McCracken (2011), 1-minute solar data was generated, based-on the existing hourly solar data found in ESP-r's climate data files. This allowed the electrical output from PV to reflect the variability observed in solar radiation levels for a maritime climate like the UK's. This variability is lost when using the hourly-averaged climate data typically used by building simulation tools. These adaptations to ESP-r are described in detail in Hand et al (2014).

Figure 1 shows typical high-temporal-resolution simulation output including appliance electrical demand and demand associated with the operation of a heat pump. 


\section{4}

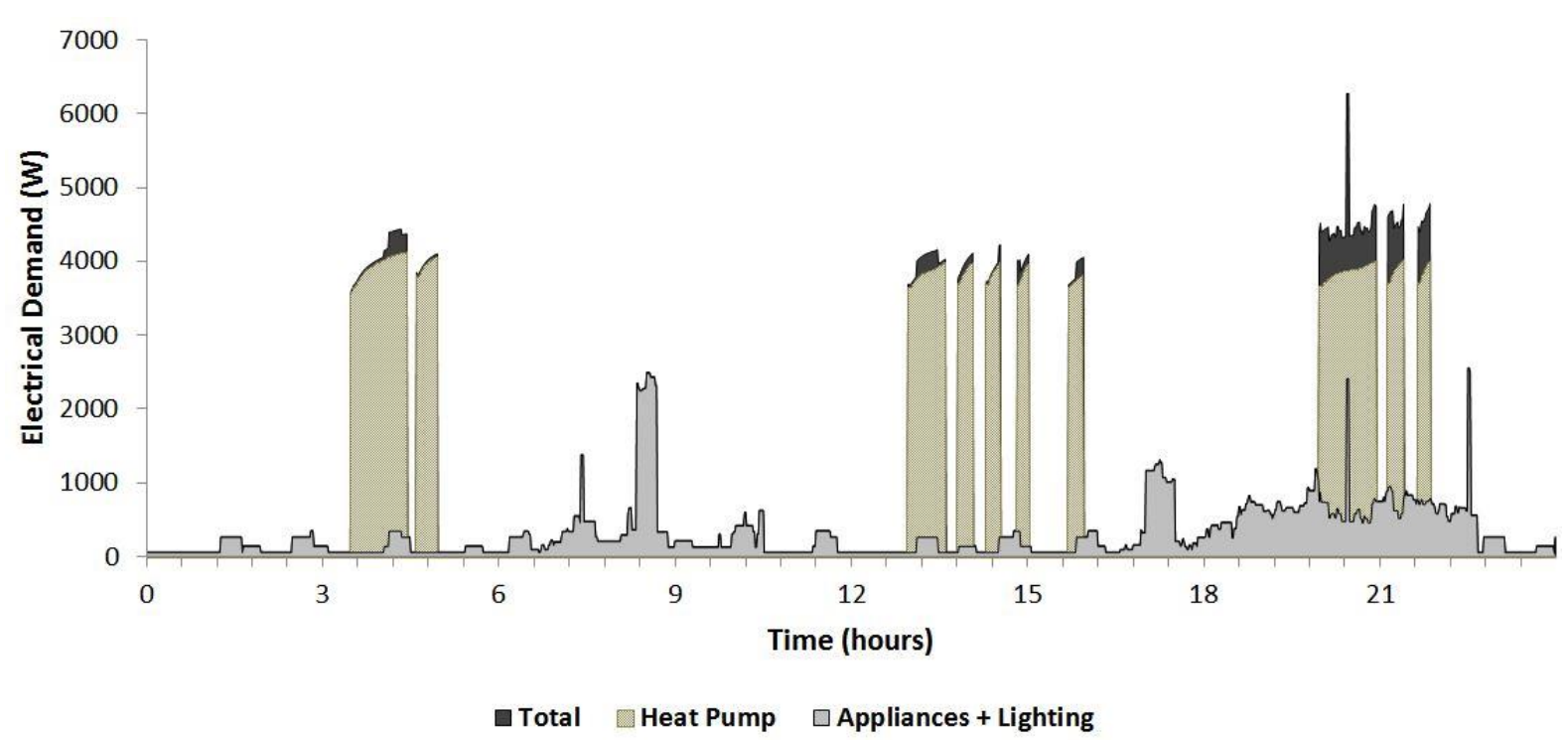

Figure 1: simulation output at 1-min time resolution.

\subsection{Vehicle and Battery Algorithm}

In addition to the high temporal resolution modifications outlined in the previous paragraphs, a stochastic, electric vehicle (EV) charging algorithm has been developed for the ESP-r tool. The primary role of this algorithm is to mimic the effect of electric vehicle charging on the dwelling's overall electrical demand. The model has several functions, these are: 1) determine when a vehicle leaves and then returns from a trip; 2) calculate the trip distance and subsequent depletion of the battery; and 3) re-charge or discharge the battery according to a user-selected control strategy.

The EV model can take four basic states: idle - the vehicle is present and not charging; absent - the vehicle is on a trip, charging - the vehicle is present and charging or discharging - the vehicle is present and discharging power back to the network. There is an explicit assumption made in the algorithm that all trips have 1 outward and 1 return leg and that the distance travelled in the return leg is the same as the outbound trip. Additionally, all charging is assumed to occur at home.

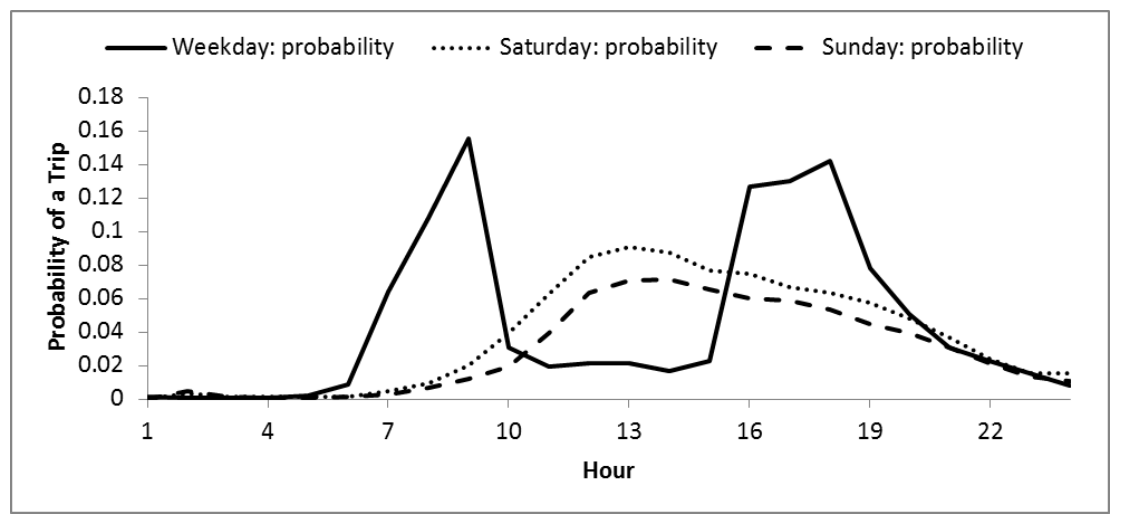

Figure 2: hourly probabilities of a trip leg being taken over a 24-hour period (Huang and Infield, 2010).

To determine if a trip leg is made, the algorithm generates a random number, $x$, at each simulation time step and this is tested against a time-dependent trip probability $p(t)$ (see Table 1) to determine:

a) whether the EV will depart on a trip (if the vehicle is present); or 
b) when it returns home from a trip (when the vehicle is absent).

The time-varying hourly probabilities for one leg of a trip for weekdays, Saturdays and Sundays are shown in Figure 2; these were taken from the 2013 UK travel survey (DFT, 2014) and Huang and Infield (2010). The probabilities needed to be modified as follows to account for sub-hourly time steps and the assumption that each vehicle trip comprises two legs.

$p(t)=p_{h}(t)\left(\frac{\Delta t}{3600}\right) n$

Here, $p_{h}(t)$ is the probability that a trip leg will be made in a particular hour, $\Delta t$ is the simulation time step and $n$ is the assumed number of legs per trip.

\begin{tabular}{|c|l|l|}
\hline \multicolumn{3}{|c}{ Table 1: vehicle status changes. } \\
\hline \multirow{2}{*}{ Test result } & Vehicle status & $\begin{array}{l}\text { Vehicle Status } \\
\text { changes to }\end{array}$ \\
\hline$x \geq p(t)$ & Home & Absent \\
\cline { 2 - 3 } & Absent & Home \\
\hline \multirow{2}{*}{$x<p(t)$} & Absent & Absent \\
\cline { 2 - 3 } & Home & Home \\
\hline
\end{tabular}

244 The model also includes an allowance for 'range anxiety'. It was assumed that if the state of charge (SOC) is below 35\% (i.e. enough charge for an average trip) then the vehicle will continue to charge and a trip will not be made. If the vehicle has returned from a trip (status has changed from 'absent' to 'home'), the model calculates a feasible distance travelled and then the state of charge of the battery. The cumulative probability of particular trip of distance $d$ taking place was characterised using a Weibull distribution with a $\lambda$ value of 22.4 and a $k$ value of 0.8 , calibrated using UK survey data (DfT, 2014)

$F=1-e^{-\left(\frac{d}{\lambda}\right)^{k}}$

251 The total distance, $d$, travelled (over the two legs) can therefore be calculated using Equation

252 3. Here, $y$ is a random number with a value between 0 and 1.

$d=\lambda(-\ln (1-y))^{k}$

This distance is checked against the time the vehicle has been absent $(\Delta t)$ and the maxium speed that the vehicle can legally travel, $v_{\max }$ giving a maximum permissible distance travelled $d_{\text {max }}=v_{\max } \Delta t / 3600$ - if the distance travelled exceeds this, then $d$ is set to $d_{\text {max }}$.

The SOC of the battery on returning from a trip is calculated using Equation 4, where $D$ is the nominal discharge rate of the battery in $\mathrm{kWh} / \mathrm{km}$ and $L$ represents any user-defined parasitic losses for the battery when the car is moving (e.g. any draws on the battery from the heating or cooling system not accounted for in D).

$\operatorname{SOC}(t+\Delta t)=\operatorname{SOC}(t)-(D+L) v$

Finally, the model encompasses a range of charging strategies, as outlined in Table 2. Depending on the strategy chosen for the model, the vehicle state will change from idle to charging on return from a trip.

Note that the random number generator in both the hot water draw algorithm, mentioned previously and the vehicle algorithm employs a seed, which generates a unique pseudorandom series. Additionally, the high resolution solar data and electrical demand use presimulated profiles. Consequently, the simulations described later are repeatable, provided that the same seeds are used in the random number generator. 
Table 2: vehicle battery charging strategy summary.

\begin{tabular}{|c|c|c|}
\hline Strategy & Comments & Criteria \\
\hline Fast charge & $\begin{array}{l}\text { Vehicle will charge at the maximum } \\
\text { allowable rate } P_{V F A S T} \text { until the battery is } \\
\text { fully charged }\end{array}$ & $S O C<S O C_{M A X}$ \\
\hline Slow charge & Vehicle charges at a reduced rate $P_{S L O W}$ & $S O C<S O C_{M A X}$ \\
\hline $\begin{array}{l}\text { Off peak fast } \\
\text { or slow charge }\end{array}$ & $\begin{array}{l}\text { Vehicle charged at } P_{V S L O W / F A S T} \text { if within } \\
\text { the off peak period } 11 \mathrm{pm}-7 \mathrm{am}\end{array}$ & $\begin{array}{l}S O C<S O C_{M A X} \\
t_{O P-S T A R T}<t<t_{O P-E N D}\end{array}$ \\
\hline $\begin{array}{l}\text { Load sensitive } \\
\text { fast or slow } \\
\text { charging }\end{array}$ & $\begin{array}{l}\text { Vehicle charged at } P_{V S L O W / F A S T} \text { only if the } \\
\text { household demand, } P_{H} \text {, is below a user } \\
\text { defined maximum, } P_{H} \text { MAX. Otherwise the } \\
\text { charging is stopped or the charging rate is } \\
\text { modulated. }\end{array}$ & $\begin{array}{l}S O C<S O C_{M A X} \\
t_{O P-S T A R T}<t<t_{O P-E N D} \\
P_{H}<P_{H M A X}\end{array}$ \\
\hline $\begin{array}{l}\text { Bi-directional } \\
\text { battery } \\
\text { operation }\end{array}$ & $\begin{array}{l}\text { Vehicle charged at } P_{V S L O W / F A S T} \text { only if the } \\
\text { household demand, } P_{H} \text {, is below a user } \\
\text { defined maximum, } P_{H M A X} \\
\text { OR } \\
\text { If the household demand exceeds } \\
P_{H M A X} \text { and the battery SOC is above the } \\
\text { minimum, the battery is discharged to help } \\
\text { meet the household load. Otherwise } \\
\text { charging is stopped }\end{array}$ & $\begin{array}{l}P_{H}<P_{H M A X} \\
\text { OR } \\
S O C>S O C_{M I N} ; \\
P_{H}>P_{H M A X}\end{array}$ \\
\hline
\end{tabular}

\subsection{Dwelling Model}

An ESP-r model of a zero-energy dwelling was used as the basis of the simulations reported in this paper - this is shown in Figure 4. The integrated model comprises the dwelling fabric and geometry, heating and ventilation system and the vehicle charging algorithm. Simulation of the model provided data on the thermal performance of the building and systems, their electrical demand and the electrical demand associated with the use of the EV.

277 The dwelling model was divided into three zones: a loft zone and two composite zones describing (respectively) the areas of the dwelling hosting active occupancy such as the living room and kitchen and those areas that have low occupancy rates or that are occupied at night such as bathrooms and bedrooms, respectively. For each of these zones the air and fabric temperature temperatures, heat fluxed and mass flows were calculated on a timestep-bytimestep basis, accounting for internal gains from occupants and appliances, climate interaction and the influence of the heating and ventilation system.

284 The geometric characteristics are summarised in Table 3; this geometrically aggregated form of the model captures the pertinent thermodynamic characteristics of the building's performance and has been deployed successfully in other studies, e.g. (Clarke et al, 2008). 


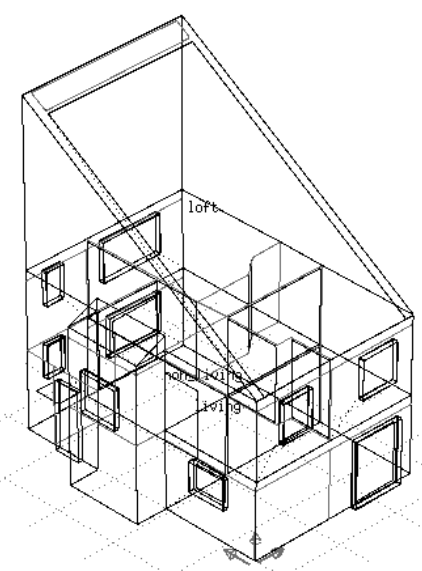

287

Figure 4. Wireframe view of the zero-energy dwelling model.

The model features a mono pitch roof to accommodate the $45 \mathrm{~m}^{2}$ ( $8 \mathrm{kWp}$ ) of PV panels, used to offset the regulated electrical demands and appliance energy demands. The PV does not offset the electrical demand of the EV. The building has a wooden frame construction, is super-insulated with triple-glazed windows, has high airtightness, mechanical ventilation heat recovery (MVHR) and meets passive house standards on energy use. The characteristics of the key fabric elements are as shown in Table 4.

Table 3: summary of dwelling geometric characteristics.

\begin{tabular}{|l|l|}
\hline Floor area $\left(\mathrm{m}^{2}\right)$ & 82.7 \\
\hline External surface area $\left(\mathrm{m}^{2}\right)$ & 151 \\
\hline Heated Volume $\left(\mathrm{m}^{3}\right)$ & 230 \\
\hline Glazed Area $\left(\mathrm{m}^{2}\right)$ & 21.45 \\
\hline 'Day' zone floor area $\left(\mathrm{m}^{2}\right)$ & 34.8 \\
\hline 'Night' zone floor area $\left(\mathrm{m}^{2}\right)$ & 47.9 \\
\hline
\end{tabular}

Table 4: characteristics of constructions used in the dwelling model.

\begin{tabular}{|l|l|l|}
\hline Construction & Details & $\begin{array}{l}\text { U-value } \\
\left.\text { (W/m }{ }^{2} \mathrm{~K}\right)\end{array}$ \\
\hline External walls & $\begin{array}{l}\text { Weatherboard air SIP panel with 300mm insulation } \\
\text { service void plasterboard 484mm }\end{array}$ & 0.104 \\
\hline Floor & $\begin{array}{l}\text { 200mm insulation under concrete slab with void and } \\
\text { carpet over plywood }\end{array}$ & 0.151 \\
\hline Ceiling & Plasterboard with 400mm glass wool 420mm & 0.098 \\
\hline Roofing & Slate roof over battens (cold roof) & 3.636 \\
\hline Glazing & Triple glazing argon filled low-e coatings 42mm & 0.89 \\
\hline
\end{tabular}




\subsubsection{Heat Pump/MVHR System and Operating Strategies}

The heating and ventilation system used in the dwelling model is shown in Figure 5; the system is modelled as a network in ESP-r, comprising a group of interconnected components, each modelled explicitly.

The air source heat pump is the primary heat source for the dwelling, with a $6 \mathrm{~kW}$ nominal heating capacity and nominal coefficient of performance (COP) of 3; both the COP and the heating capacity of the ASHP vary with the ambient temperature and the 500L buffer tank temperature which it charges. The buffer allows the heat pump to be operated flexibly in time: the heat pump charges the thermal buffer, which then supplies the heat for space heating and hot water at a later time. The development and verification of the heat pump model is described in more detail by Kelly and Cockroft (2011) and Kelly et al (2014).

The heating system model also includes a dedicated $500 \mathrm{~L}$ domestic hot water (DHW) tank and $3 \mathrm{~m}^{2}$ of roof-mounted solar thermal collectors. The tank is heated from the ASHP buffer tank and from the roof mounted collectors. The draw from the DHW tank is calculated using the stochastic hot water demand algorithm mentioned previously. An additional feature of the systems model is a $200 \mathrm{~L}$ grey water heat recovery tank (GWHR): this uses the waste hot water to pre-heat the incoming cold-feed to the DHW tank via a heat exchanger. The model assumes that the energy content of the waste hot water is $80 \%$ of that drawn from the DHW tank. All of the tanks modelled account for thermal stratification and standing losses.

The ventilation system includes a heat exchanger and supply and extracts fans. Both fans are assumed to operate continuously and the flow through both each is $0.026 \mathrm{~m}^{3} / \mathrm{s}$, providing a ventilation rate of 0.4 air changes per hour. Their combined power draw is $36 \mathrm{~W}$. The heat exchanger has an effectiveness of $80 \%$. The ventilation system supply and extract branches are coupled directly to the day and night zones of the building model.

Solution of the systems model provides time-series data on the temperatures of the individual components, inter-component heat and mass transfer and where appropriate their primary energy use, accounting for control action and the influence of the climate and indoor conditions in the dwelling. 


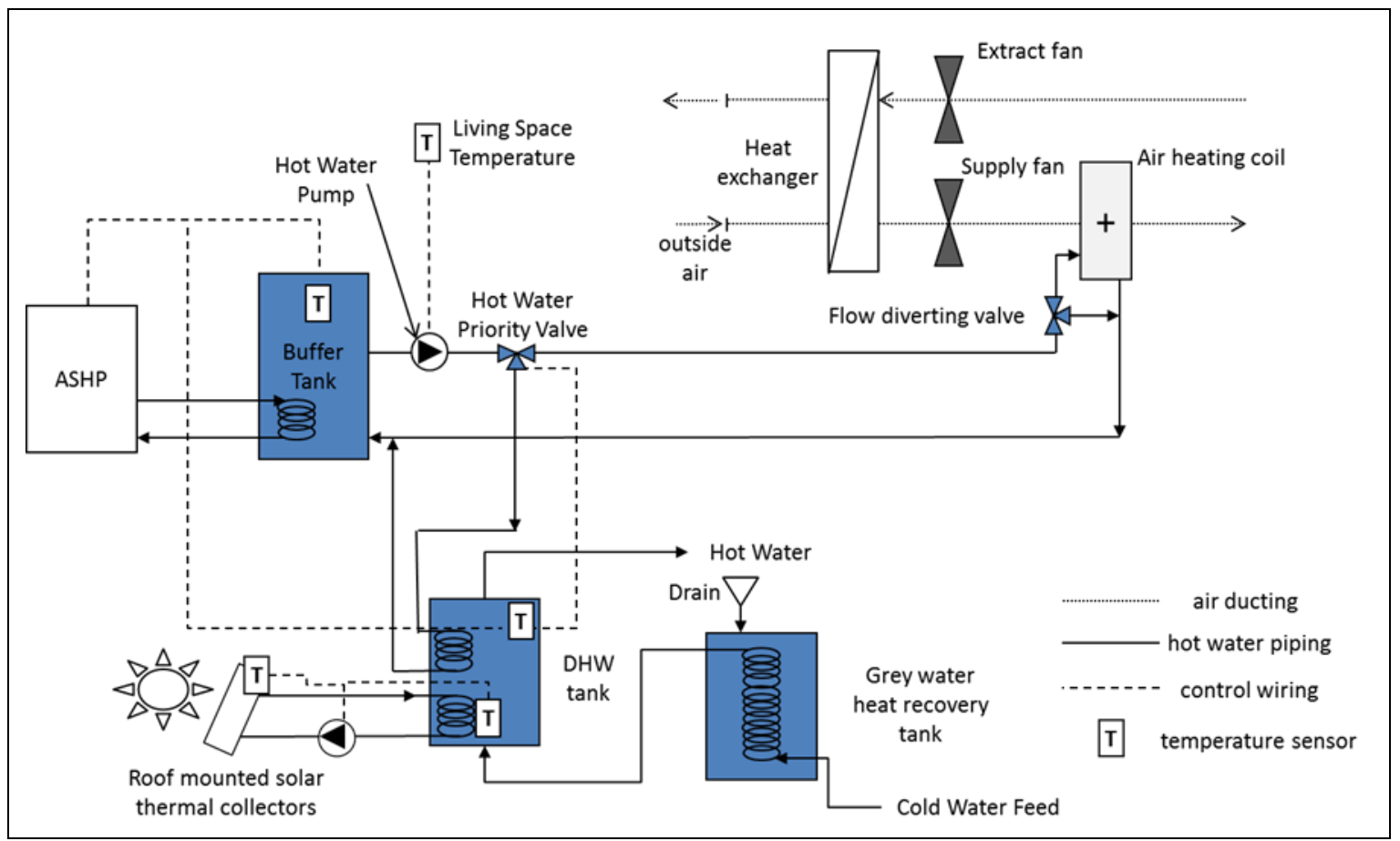

Figure 5: systems model for the dwelling.

\subsubsection{System Control Strategy}

329 Three operating strategies were used with the heat pump, there are shown in Table 5; these place different restrictions on when the heat pump can operate.

Table 5: heat pump operating restrictions.

\begin{tabular}{|l|l|}
\hline $\begin{array}{c}\text { Time-based control } \\
\text { (unrestricted } \\
\text { operation during } \\
\text { active occupancy) }\end{array}$ & $\begin{array}{l}\text { Intermittent dwelling occupancy is assumed and the heat pump is free } \\
\text { to operate at any point between } 0600 \text { and } 0900 \text { hrs and } 1600 \text { and } 2300 \\
\text { hrs. }\end{array}$ \\
\hline Off-peak operation & $\begin{array}{l}\text { The operation of the heat pump is restricted to the period between } \\
\text { 0000-0700 hrs }\end{array}$ \\
\hline $\begin{array}{l}\text { Load sensitive } \\
\text { operation }\end{array}$ & $\begin{array}{l}\text { The heat pump can to operate at any point between } 0600 \text { and } 0900 \mathrm{hrs} \\
\text { and } 1600 \text { and } 2300 \text { hrs. However, if the total household electrical } \\
\text { demand exceeds 7.5kW, the operation of the heat pump is halted until } \\
\text { demand falls below this level. }\end{array}$ \\
\hline
\end{tabular}

The general control strategy for the heat pump is that, when able to operate, it is to maintain the buffer tank temperature between 50 and $55^{\circ} \mathrm{C}$, (on/off control with a $10^{\circ} \mathrm{C}$ dead band), with the circulating pump then providing heat for the hot water tank and heating coil if there is a requirement for either space heating or hot water. Ideally, the DHW tank is maintained between $43-45^{\circ} \mathrm{C}$. The flow to the heating coil in the MVHR system is modulated using a valve component to maintain space temperatures, where possible, between 19 and $22^{\circ} \mathrm{C}$.

As is common in UK heating systems, priority is given to hot water - the hot water priority valve diverts all of the heat supply to the hot water tank if this is below the set point temperature. Only when the hot water tank is between 43 and $45^{\circ} \mathrm{C}$ is heat supplied to the heating coil. 
346

347

348

349

350

351

352

353

354

355

356

357

358

359

360

361

362

363

364

365

366

\subsubsection{Electric Vehicle}

The EV charging model used in the simulations is calibrated to be representative of a Nissan Leaf (Nissan, 2014) with the key model parameters are shown in Table 6.

Table 6: key EV model characteristics (Nissan, 2014; DFT, 2014).

\begin{tabular}{|l|l|}
\hline Battery capacity $(\mathrm{kWh})$ & 24 \\
\hline Fast charging power $(\mathrm{kW})$ & 6.6 \\
\hline Slow charging power $(\mathrm{kW})$ & 3.0 \\
\hline Minimum (SOC \%) & 20 \\
\hline Range anxiety (SOC \%) & 35 \\
\hline Charge/discharge efficiency $(\%)$ & 90 \\
\hline Discharge rate (kWh/km) & 0.15 \\
\hline Nominal annual distance travelled $(\mathrm{km})$ & 13,600 \\
\hline Nominal trip distance $(\mathrm{km})$ & 22.1 \\
\hline Distance equation ' $\lambda$ ' (-) & 22.4 \\
\hline Distance equation ' $\mathrm{k}$ ' (-) & 0.8 \\
\hline
\end{tabular}

\subsubsection{Electrical Power Flows}

Whilst calculating the thermal performance of the dwelling and its system, the model also tracks the overall, time-varying electrical performance, accounting for the electrical generation from the PV rooftop installation, electrical demands associated with the ASHP and ventilation system, appliance demand and resultant real power exchange with the network. As this is a domestic example, reactive power flows were not considered.

\section{METHOD}

A scenario-based approach was adopted in order to assess the impact of the different combinations of heating control and EV charging strategies. A total of 16 cases were investigated, covering different combinations of charging and heating strategy and a base case which excludes the demand from the heat pump and EV, the assumption being made that these services are provided by other (non-electrical) energy sources, as typically occurs at present in the UK. In other countries where electric heating is the norm, the difference between base case and fully electrified cases would be less stark. All of the cases modelled are summarised in Table 7.

All of the scenarios were simulated at 1-minute time resolution over the winter months of January and February using a southern UK climate data set. A winter period such as this constitutes a 'worst case scenario' for electrical demand, as the dwelling heating demand will be at its highest, PV output at its lowest.

\section{Table 7 Scenarios modelled.}

\begin{tabular}{|l|l|}
\hline $\begin{array}{l}\text { Base Case - no EV, no } \\
\text { Heat Pump }\end{array}$ & $\begin{array}{l}\text { The house is assumed to be heated using an alternative low-carbon heat } \\
\text { source such as biomass and there is no EV. }\end{array}$ \\
\hline $\begin{array}{l}\text { Case } 1-\text { unrestricted }+ \\
\text { slow charging }\end{array}$ & $\begin{array}{l}\text { Both heating system operation and vehicle charging are unrestricted. } \\
\text { The vehicle is slow charged at } 3.3 \mathrm{~kW} \text { when it returns from trips and }\end{array}$ \\
\hline
\end{tabular}




\begin{tabular}{|c|c|}
\hline & heat is supplied when required. \\
\hline $\begin{array}{l}\text { Case } 2 \text { - unrestricted }+ \text { fast } \\
\text { charging }\end{array}$ & $\begin{array}{l}\text { Both heating system operation and vehicle charging are unrestricted. } \\
\text { The vehicle is fast charged at } 6.6 \mathrm{~kW} \text { when it returns from trips and heat } \\
\text { is supplied when required. }\end{array}$ \\
\hline 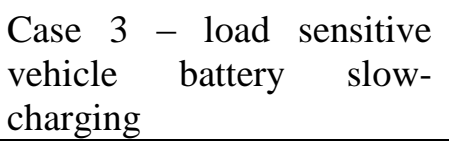 & $\begin{array}{l}\text { The vehicle battery is charged at } 3.3 \mathrm{~kW} \text { if the dwelling and vehicle } \\
\text { demand would be less than } 7.5 \mathrm{~kW} \text {. Heat pump operation is } \\
\text { unrestricted. }\end{array}$ \\
\hline $\begin{array}{l}\text { Case } 4-\text { load sensitive } \\
\text { vehicle battery fast- } \\
\text { charging }\end{array}$ & $\begin{array}{l}\text { The vehicle battery is charged at } 6.6 \mathrm{~kW} \text { when the overall dwelling and } \\
\text { vehicle demand would be less than } 7.5 \mathrm{~kW} \text {. Heat pump operation is } \\
\text { unrestricted. }\end{array}$ \\
\hline $\begin{array}{l}\text { Case } 5 \text { - off-peak heating } \\
\text { and unrestricted slow } \\
\text { charging }\end{array}$ & $\begin{array}{l}\text { The heating buffer tank (Figure } 5) \text { is charged by the heat pump during } \\
\text { off peak periods }(11 \mathrm{pm}-7 \mathrm{am}) \text {; vehicle battery charging at } 3.3 \mathrm{~kW} \text { is } \\
\text { unrestricted. }\end{array}$ \\
\hline $\begin{array}{l}\text { Case } 6 \text { - off peak heating } \\
\text { and unrestricted fast } \\
\text { charging }\end{array}$ & $\begin{array}{l}\text { The heating buffer tank (figure } 5) \text { is charged by the heat pump during } \\
\text { off peak periods }(11 \mathrm{pm}-7 \mathrm{am}) \text {; vehicle battery charging at } 6.6 \mathrm{~kW} \text { is } \\
\text { unrestricted. }\end{array}$ \\
\hline $\begin{array}{l}\text { Case } 7-\text { off peak } \\
\text { battery } \quad \text { charging } \\
\text { heating }\end{array}$ & $\begin{array}{l}\text { Both slow vehicle charging at } 3.3 \mathrm{~kW} \text { and heat pump operation are } \\
\text { shifted to off peak periods }(11 \mathrm{pm}-7 \mathrm{am}) \text {. }\end{array}$ \\
\hline $\begin{array}{lcc}\text { Case } 8 & - \text { off-peak } & \text { fast } \\
\text { battery } & \text { charging } & \text { and } \\
\text { heating } & & \\
\end{array}$ & $\begin{array}{l}\text { Both fast vehicle charging at } 6.6 \mathrm{~kW} \text { and heat pump operation are } \\
\text { shifted to off peak periods }(11 \mathrm{pm}-7 \mathrm{am}) \text {. }\end{array}$ \\
\hline $\begin{array}{l}\text { Case } 9 \text { - load sensitive heat } \\
\text { pump and slow battery } \\
\text { charge }\end{array}$ & $\begin{array}{l}\text { The heat pump only operates if the dwelling demand is below } 7.5 \mathrm{~kW} \text {. } \\
\text { Vehicle charging at } 3.3 \mathrm{~kW} \text { is unrestricted. }\end{array}$ \\
\hline $\begin{array}{l}\text { Case } 10-\text { load sensitive } \\
\text { heat pump and fast battery } \\
\text { charge }\end{array}$ & $\begin{array}{l}\text { The heat pump only operates if the dwelling demand is below } 7.5 \mathrm{~kW} \text {. } \\
\text { Vehicle charging at } 6.6 \mathrm{~kW} \text { is unrestricted. }\end{array}$ \\
\hline $\begin{array}{l}\text { Case } 11-\text { bi-directional } \\
\text { slow battery charging/ } \\
\text { discharging }\end{array}$ & $\begin{array}{l}\text { The vehicle battery is only charged at } 3.3 \mathrm{~kW} \text { when the overall dwelling } \\
\text { and vehicle demand would be less than } 7.5 \mathrm{~kW} \text {. Otherwise the vehicle } \\
\text { battery charging is reduced or if necessary it is discharged to limit the } \\
\text { peak load. Heat pump operation is unrestricted. }\end{array}$ \\
\hline $\begin{array}{l}\text { Case } 12-\text { bi-directional } \\
\text { fast battery charging/ } \\
\text { discharging }\end{array}$ & $\begin{array}{l}\text { The vehicle battery is only charged at } 6.6 \mathrm{~kW} \text { when the overall dwelling } \\
\text { and vehicle demand would be less than } 7.5 \mathrm{~kW} \text {. Otherwise the vehicle } \\
\text { battery charging rate is reduced or if necessary it is discharged to limit } \\
\text { the peak demand. Heat pump operation is unrestricted. }\end{array}$ \\
\hline $\begin{array}{l}\text { Case } 13-\text { load sensitive } \\
\text { slow battery charging and } \\
\text { heat pump use }\end{array}$ & $\begin{array}{l}\text { Heat pump operation and vehicle charging at } 3.3 \mathrm{~kW} \text { only occur if } \\
\text { dwelling demand is below } 7.5 \mathrm{~kW} \text {. Heat pump operation is prioritised. }\end{array}$ \\
\hline $\begin{array}{l}\text { Case } 14-\text { load sensitive } \\
\text { fast battery charging and } \\
\text { heat pump use }\end{array}$ & $\begin{array}{l}\text { Heat pump operation and vehicle charging at } 6.6 \mathrm{~kW} \text { only occur if } \\
\text { dwelling demand is below } 7.5 \mathrm{~kW} \text {. Heat pump operation is prioritised. }\end{array}$ \\
\hline $\begin{array}{l}\text { Case } 15-\text { bi-directional } \\
\text { slow battery charging and } \\
\text { load sensitive heat pump }\end{array}$ & $\begin{array}{l}\text { Heat pump and vehicle charging at } 3.3 \mathrm{~kW} \text { can only occur if the } \\
\text { dwelling demand is below } 7.5 \mathrm{~kW} \text {. Otherwise the battery charging rate } \\
\text { is reduced or if necessary it is discharged to meet the household load. } \\
\text { Heat pump operation is prioritised. }\end{array}$ \\
\hline Case 16 - bi-directional & Heat pump and fast vehicle charging only occur if the dwelling demand \\
\hline
\end{tabular}


slow battery charging and load sensitive heat pump is below $7.5 \mathrm{~kW}$. Otherwise the battery charging rate is reduced or if necessary it is discharged to meet the household load. Heat pump operation is prioritised.

Note that where the vehicle charging or heat pump operation was modulated according to the demand limit of $7.5 \mathrm{~kW}$, demand may still rise above this level due to the power use from other appliances in the house. Further, breaches of the demand limit may occur in the cases where the vehicle battery is allowed to discharge to limit demand if the vehicle is absent on a trip and unable to contribute.

\section{RESULTS AND DISCUSSION}

Three different elements of performance were reviewed using the results from the scenarios listed in Table 7. These were as follows.

1. The combined electrical demand of the dwelling and vehicle, specifically looking at the mean peak demand, load duration and the overall electrical energy use were analysed in order to gauge the effect of the different peak demand limiting measures tested.

2. The performance of the EV over the simulated period was reviewed, looking at the number of trips and distance travelled to determine if the demand limiting measures had any significant impact on the vehicle use.

3. The energy performance of the heating system was analysed, particularly the indoor air temperatures and hot water temperatures, in order to determine if heat pump load management measures had any adverse impact on the comfort of building occupants or reduced the availability of hot water.

The simulation results are summarised in Tables $8 \mathrm{a}-8 \mathrm{c}$. The following paragraphs review general trends emerging from the simulations, followed by more specific reviews of the different charging strategies.

\section{Electrical Energy Use}

As would be expected, the use of an electric vehicle and the electrification of domestic heating results in an electrical energy demand more than double the electrical consumption compared to the base case over the simulated period. In the base case, only appliance demand in considered, as it is assumed that heating and transport are assumed to be provided by nonelectric means. The use of the EV and heat pump also increased the self-consumption of PV generated electricity and decreased the amount of power exported to the grid. This is shown in Figure 7, the data for which can be seen in Table 8a.

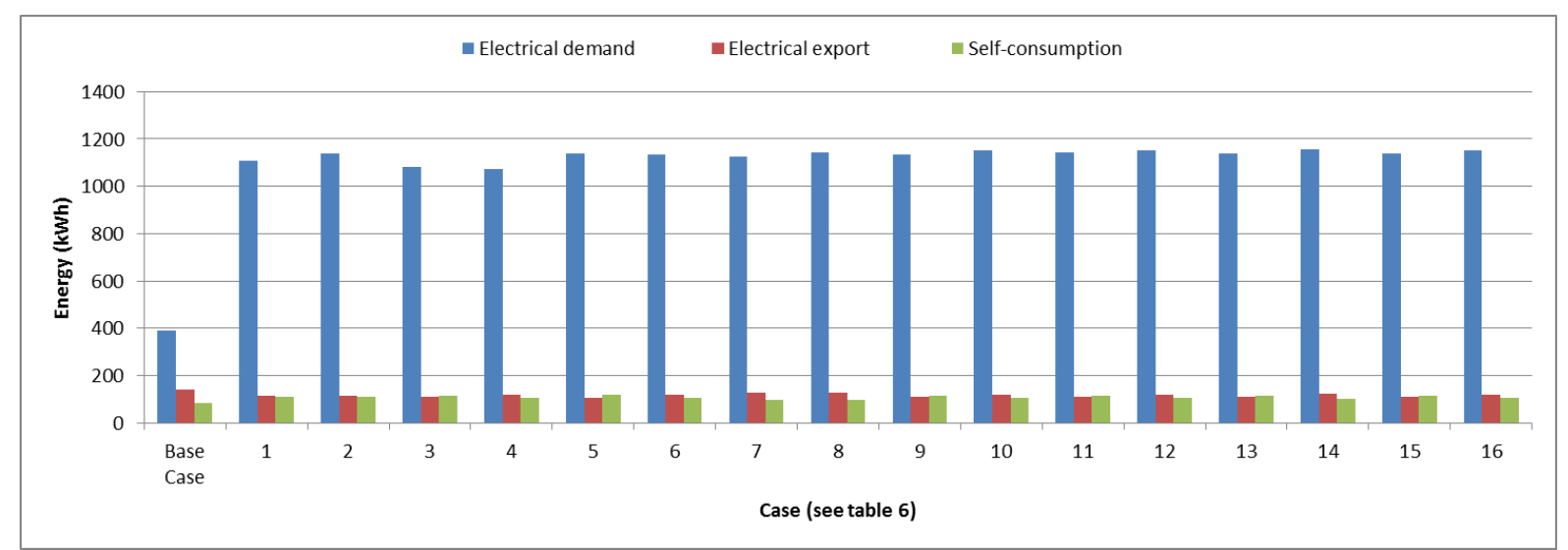

Figure 7 electrical energy demand, export and self-consumption for each case simulated. Instantaneous Demand 
Figure 8 shows the two demand metrics culled from the simulations - the absolute peak demand and mean daily peak demand (the sum of the each daily peak demand divided by the number of days simulated - 59). The efficacy of the specific demand limiting measures in relation to each of these metrics is discussed below. However, some general trends are evident across all of the cases simulated. First, the mean and absolute peak demands increase compared to the base case, no matter what demand limiting strategy adopted. Secondly, fast charging results in higher mean and absolute peak demands in all cases, though the difference between the two could be minimised, as will be discussed later.

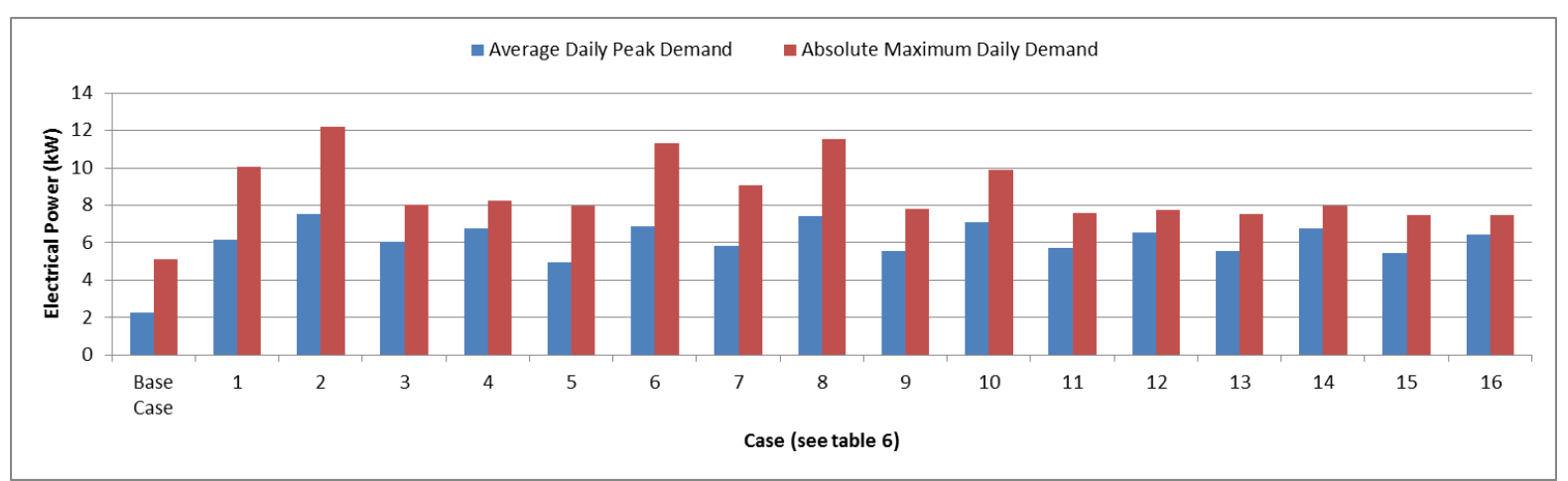

Figure 8 average daily peak demand and absolute peak demand for each case simulated.

\section{Unrestricted Charging and Heating}

Comparing the results from Scenarios 1 and 2 shown in Table 8a (unrestricted slow and fast vehicle charging, respectively, and unrestricted heating operation) to the base case, indicates that for the two winter months simulated the electrical energy use increased from approximately $390 \mathrm{kWh}$ for the base case to over $1000 \mathrm{kWh}$ in all other scenarios. The mean daily peak electrical demand in the base case was $2.29 \mathrm{~kW}$, this increased to $6.15 \mathrm{~kW}$ with unrestricted heating operation and unrestricted slow charging and $7.53 \mathrm{~kW}$ with unrestricted heating and fast charging. The corresponding absolute peak demands were 10.08 and 12.22 $\mathrm{kW}$ respectively. Figures $6 \mathrm{a}$ and $6 \mathrm{~b}$ show the resulting electrical demand profiles for a typical day.

Table $8 \mathrm{~b}$ shows the maximum charge times, these were 328 minutes with slow charging, and 172 minutes with fast charging. With slow charging, the vehicle was used for 107 trips and 112 with fast charging. The distance travelled with fast charging was $2588 \mathrm{~km}$ compared to $2388 \mathrm{~km}$ with slow charging. In both the fast and slow charging cases, the self-consumption of PV-generated electricity (Table 8a) was increased at the expense of electricity exported to the network. In the base case, for the two months simulated, self-consumption was $84.4 \mathrm{kWh}$, whilst $139 \mathrm{kWh}$ of electricity was exported. With the addition of the EV and heat pump, selfconsumption in the slow and fast charging cases rose to 111 and $108 \mathrm{kWh}$, respectively. Electrical exports dropped to 113 and $116 \mathrm{kWh}$, respectively, over the same period. The same trend was evident in all of the other 14 scenarios simulated.

\section{Demand Limited Vehicle Charging}

For Scenarios 3 and 4, charging of the battery was subject to a demand limit of $7.5 \mathrm{~kW}$, with charging being modulated or stopped if the household demand (including the heat pump) exceeded this limit. Table 8a shows the mean daily peak household demand occurring in these scenarios, this was $6.03 \mathrm{~kW}$ in the slow charging case and $6.78 \mathrm{~kW}$ with fast charging. The corresponding absolute peak demands were 8.01 and $8.25 \mathrm{~kW}$ respectively. The demand limiting strategy made little difference to the mean peak daily demands (compared to unrestricted vehicle charging); however, it did limit the absolute peak demand and reduced the difference between the mean and absolute peak demand values. 
438 The maximum battery charge time (Table $8 \mathrm{~b}$ ) increased slightly for slow charging from 328

439 to 368 minutes and for fast charging from 172 to 190 minutes, indicating that some

440 modulation of both the and slow fast charge occurred due to the $7.5 \mathrm{~kW}$ constraint. The 441 modulation of full-power charging is clearly shown in Figure 6d. The total number of trips 442 taken was 111 and 109 in the slow and fast charging cases, respectively. This indicated that 443 the demand limiting strategy had little impact on vehicle use.

\section{Off Peak Heating}

445 Figures 6e and 6f show a typical daily demand profile for this strategy, with the heat pump 446 charging the buffer tank during the night. Table 8a shows that the mean, daily peak electrical demands in these scenarios were 4.96 and $6.98 \mathrm{~kW}$ for fast and slow charging, respectively. The corresponding absolute values were 7.96 and $11.33 \mathrm{~kW}$, respectively. The combination of slow charging and off-peak heating proved effective at limiting the increase in peak demand compared to the base case. However, fast charging coupled with heat pump load shifting was ineffective, particularly at limiting the absolute peak demand.

The heat pump's energy use reduced slightly from approximately $280 \mathrm{kWh}$ to $270 \mathrm{kWh}$ compared to the cases where the heat pump operation was unrestricted. However, this was not a genuine energy saving as it resulted from the restricted operational hours. Further, the shift to off-peak heating increased the occurrence of low air temperatures (defined here as air temperatures below $18^{\circ} \mathrm{C}$ ) in the dwelling to approximately $4 \%$ of occupied hours, as shown in Table $8 \mathrm{c}$, indicating a deterioration in heating system performance with load shifting.

\section{Off Peak Heating and Vehicle Charging}

459 In scenarios 7 and 8, both the charging of the vehicle and the operation of the heat pumps were restricted to off peak periods; this resulted in mean daily peak demands of 5.81 and $7.45 \mathrm{~kW}$ for slow and fast charging, respectively (Table 8a). Absolute peak demands were 9.09 and $11.57 \mathrm{~kW}$ respectively. This strategy proved ineffective at limiting peak demands in that it had the effect of synchronising both the heating and vehicle demand.

Table $8 \mathrm{~b}$, shows a slight reduction in the number of trips taken: down from approximately 110 and over in the other scenarios to 103 and 105 for the slow and fast charging scenarios, respectively. The mean SOC of the battery was also lower than in the previous cases (Table $8 b)$, though the total distance travelled was similar.

The performance of the heating system was very similar to scenarios 5 and 6 , with Table $8 \mathrm{c}$ showing that air temperatures drop below $18^{\circ} \mathrm{C}$ for approximately $4 \%$ of occupied hours.

\section{Load Limited Heating}

For scenarios 9 and 10, the operation of the heat pump was interrupted if the household demand exceeded $7.5 \mathrm{~kW}$; however the charging of the electric vehicle was not restricted. The mean daily peak demands for these scenarios where 5.57 and $7.07 \mathrm{~kW}$ for slow and fast charging, respectively. The corresponding peak demands were 7.82 and $9.91 \mathrm{~kW}$.

The restricted operation of the heat pump had virtually no effect on either the heat pump energy use or comfort conditions in that the occurrence of low air and water temperatures was negligible. Figures $6 \mathrm{i}$ and $6 \mathrm{j}$ illustrate the operation of the heat pump being curtailed during periods of vehicle charging with the heat pump operating to recharge the buffer tank after vehicle battery charging was complete, typically later in the evening.

\section{Bi-directional Battery Operation}

481 The operation of the battery was changed for scenarios 11 and 12, such that charging could 482 be curtailed, or if necessary the battery discharged, to help maintain the peak household 
demand at $7.5 \mathrm{~kW}$. The operation of the heat pump was not restricted. In these cases, the mean peak daily household demands during the simulated period were 5.71 and $6.55 \mathrm{~kW}$ for fast and slow charging, respectively. The corresponding peak demands were 7.61 and $7.78 \mathrm{~kW}$ respectively. What is noticeable from the results is that the discharge of the battery to help restrict demand to the $7.5 \mathrm{~kW}$ was rarely required. In the case where the battery could charge or discharge at the slow rate of $3.3 \mathrm{~kW}$, discharging occurred only once for a period of 6 minutes over the whole 2 month simulation period. Similarly, the battery was discharged once for a total of 10 minutes when the fast charging or discharging rate of $6.6 \mathrm{~kW}$ was used. The bulk of the peak demand management was achieved through modulation of the battery charging rate as is shown in illustrated 6l. The number of trips made was 106 and 102 for fast and slow charging respectively, again indicating that the modulating of the charging rate had a minimal effect on the use of the vehicle.

\section{Demand Limited Charging and Heating}

In Scenarios 13 and 14, the operation of both the heat pump and vehicle charging were restricted if the household demand exceeded $7.5 \mathrm{~kW}$. In scenario 11 the vehicle battery could be charged at $3.3 \mathrm{~kW}$ and in scenario 12 , fast charging at $6.6 \mathrm{~kW}$ was applied. The mean peak daily household electrical demands seen were 5.54 and $6.78 \mathrm{~kW}$. The corresponding absolute peak demands were 7.53 and $7.97 \mathrm{~kW}$.

The restrictions on the charging of the battery and heat pump operation seemed to make little difference to their performance. For the vehicle, the number of trips made and distance travelled was similar to the other cases simulated. The modulation of the battery charging lengthened the battery charging times, particularly fast charging, with the maximum fast charging time being 214 minutes, which was longer than the 172 minutes for Case 2 where the unrestricted fast charging time was 172 minutes.

For the heat pump, the demand limited operation had very little effect, with the occurrence of low hot water and indoor temperatures being less than $1 \%$ of simulated hours in both cases. Indeed, as the heat pump was given priority over the battery charging in these cases, the battery charging was the main mechanism for peak load limiting.

\section{Bi-directional Battery Operation and Demand Limited Heating}

In the final two Scenarios 15 and 16, the battery was able to charge/discharge at 3.3 and $6.6 \mathrm{~kW}$, respectively. The heat pump operation was restricted so that above a household demand of $7.5 \mathrm{~kW}$ its operation was curtailed. The mean peak household demands occurring in these scenarios were $5.47 \mathrm{~kW}$ and $6.42 \mathrm{~kW}$ respectively. The corresponding absolute peak demands were 7.48 and $7.49 \mathrm{~kW}$ respectively.

As was seen in Scenarios 11 and 12, the discharge of the battery in order to limit household demand rarely occurred, with the battery not being discharged at all in the case where charging/discharging rate was set at $3.3 \mathrm{~kW}$ and discharging only once for a 1-minute period where the charging/discharging rate was set at $6.6 \mathrm{~kW}$. The number of trips made and distance travelled were comparable to cases where the vehicle charging was unrestricted. The impact on the heat pump from the $7.5 \mathrm{~kW}$ demand restriction was negligible, with air temperatures being below $18^{\circ} \mathrm{C}$ for less than $1 \%$ of the simulated period and negligible occurrence of low hot water temperatures.

\section{CONCLUSIONS}

A detailed model of a hypothetical, UK zero carbon dwelling has been developed in order to explore the impact of wholesale electrification of heating and electric vehicle charging. The model was simulated at a 1-minute resolution, in order to capture the volatility of electrical 
529 demand. The simulation used a southern UK climate data set and covered the period January

530 to February, the worst case period for heating demand and local generation from the solar PV 531 integrated into the dwelling.

532 A number of different approaches to limit the peak demand for electricity were tested singly 533 and in combination, these included fast and slow vehicle charging, demand-limited vehicle 534 charging and heating use, off-peak heating and vehicle charging, and bi-directional battery 535 operation, allowing the battery to discharge in support of peak electrical demand attenuation.

536 A variety of metrics were used to assess the success or otherwise of the electrical demandlimiting strategies. These included the absolute and mean daily peak demand, the number of journeys taken in the vehicle and the internal air temperature in the dwelling.

539 Key points emerging from these simulations were as follows.

540 The operating strategy which proved the most successful at minimising the impact of 541 electrification on the mean daily peak electrical demand was slow vehicle charging, coupled 542 with off-peak heat pump use between $11 \mathrm{pm}$ and $7 \mathrm{am}$.

543 Load shifting both the vehicle charging and heat pump operation proved counterproductive, 544 in limiting the rise in instantaneous demand as dual load shifting inadvertently synchronised 545 both of these large loads.

546 The combination of both load sensitive heating and load sensitive vehicle charging proved 547 effective at limiting both the rise in mean daily peak and absolute peak demand. The strategy 548 also significantly reduced the difference between the mean daily and absolute peak demands.

549 Load sensitive heat pump operation and battery charging almost eliminated the difference in 550 peak demands seen between fast and slow charging.

551 Where the vehicle battery was allowed to discharge in support of peak demand limiting, discharge very rarely occurred when the demand limit was set to $7.5 \mathrm{~kW}$.

553 Finally, as has been seen in previous studies (e.g. Munkhammar et al, 2013), in all of the cases simulated, the electrical energy use more than doubled in comparison to the base case (which had neither electric vehicle nor electric heating). Peak demand limiting measures have no impact on the rise in electrical energy demand.

\section{LIMITATIONS}

558 This paper looks only at the impacts of wholesale electrification and demand limiting 559 measures on a specific, hypothetical, zero carbon UK dwelling. As with all modelling 560 exercises, the outcomes must be viewed against the limitations of the model, particularly 561 regarding the power demand of the heat pump and electric vehicle. Both of the algorithms 562 used to model these technologies rely on calibration and the data used to do this was contemporary, consequently the power demand and operation of both of these technologies may not precisely reflect that seem in a future buildings. Hence, whist the results of this study provide some insight into the impact of the demand limiting measures examined at the individual building level, they do not provide an accurate picture of future domestic demand and demand manipulation. Further, the results cannot be generalised to other building types and larger number of dwellings; this will require a more extensive analysis of a wider spectrum of the housing stock.

\section{7. ACKNOWLEDGEMENTS}

571 The simulation work described in this article was done with the support of the Top and Tail 572 Grand Challenge in Energy Networks research consortiums and the authors gratefully 
573 acknowledge the funding and support provided by the UK Research Council's Energy

574 Programme under grant EP/I031707/1.

\section{8. REFERENCES}

576

577

578

579

580

581

582

583

584

585

586

587

588

589

590

591

592

593

594

595

596

597

598

599

600

601

602

603

604

605

606

607

608

609

610

611

612

613

614

Asare-Bediako B., Kling W.L., Ribeiro P.F., 2014. Future residential load profiles: Scenariobased analysis of high penetration of heavy loads and distributed generation, Energy and Buildings, Volume 75, Pages 228-238.

Attia S, Hamdy M, O'Brien W, Carlucci S, 2013. Assessing gaps and needs for integrating building performance optimization tools in net zero energy buildings design, Energy and Buildings, Volume 60, Pages 110-124.

Clarke J A, 2001, Energy Simulation in Building Design ( $2^{\text {nd }}$ Ed.) Butterworth Heinmann, Oxford.

Clarke J A, Johnstone C M, Kim J M and Tuohy P G, 2008. Energy, Carbon and Cost Performance of Building Stocks: Upgrade Analysis, Energy Labelling and National Policy Development. Advances in Building Energy Research. 3, Earthscan, London. Pages 1-20.

DECC, Department for Energy and Climate Change 2008. The UK Low Carbon Transition Plan. The Stationary Office, London, UK.

DECC, Department for Energy and Climate Change, 2013. Energy Consumption in the United Kingdom: 2012, DECC Factsheet URN 13D/154, London, UK.

DFT, UK Department for Transport 2014. On-line Vehicle Registration Statistics: https://www.gov.uk/government/collections/vehicles-statistics Accessed: 10/06/14.

www.esru.strath.ac.uk/Programs/ESP-r.htm Accessed: 17/1/2014.

Haines G, McGordon A, Jennings P, Butcher N, 2009 The Simulation of Vehicle-to-Home Systems - Using Electric Vehicle Battery Storage to Smooth Domestic Electricity Demand. Proc. Ecologic Vehicles/Renewable Energies - EVRE, Monaco. Pages 1-9.

Hand J, Kelly N J, Samuel A, 2014. High Resolution Modelling for Performance Assessment of Future Dwellings, Proc. BSO'14 Building Simulation and Optimisation, University College London, UK, Pages 1-8.

Hawkes, A, Leach, M., 2005. Impacts of temporal precision in optimisation modelling of micro-Combined Heat and Power. Energy 30, Pages 1759-1779.

Hedegaard K, Ravn H, Juul N, Meibom P, 2012. Effects of electric vehicles on power systems in Northern Europe, Energy, Volume 48, Issue 1, Pages 356-368.

Hinnells M, Boardman B, Darby S, Killip G, Layberry R. 2007. Transforming UK homes: achieving a 60\% cut in carbon emissions by 2050 Proc. eceee 2007 Summer Study, La Colle sur Loup, France. Pages 1105-1109.

Huang S, Infield, D 2010. The impact of domestic Plug-in Hybrid Electric Vehicles on power distribution system loads, 2010 International Conference on Power System Technology (POWERCON), Hanzhou, China, pp.1-7.

IEA, 2014. International Energy Agency, Energy Conservation in Buildings and Community Systems Annex 42, www.ecbcs.org/annexes/annex42.htm Accessed 11/05/14

Jordan U and Vajen K, 2005. DHWCALC: Program to Generate Domestic Hot Water Draws with Statistical Means for User Defined Conditions, Proc. ISES Solar World Congress, Orlando, USA. Pages 1-8. 
615 Kelly N J, 1998, Towards a design environment for building integrated energy systems: the 616 integration of power flow modelling with building simulation, $\mathrm{PhD}$ Thesis, University of 617 Strathclyde, Glasgow.

618 Kelly N J, Cockroft J, 'Analysis of retrofit air source heat pumps performance: results from 619 detailed simulations and comparison to field trial data', Energy and Buildings 43 (1) pp239$620245,2011$.

Kelly N J, Tuohy P, Hawkes A, 2014. Performance assessment of tariff-based air source heat pump load shifting in a UK detached dwelling featuring phase change-enhanced buffering. Applied Thermal Engineering, 71(2), Pages 809-820.

624 Knight I and Ribberink H, 2007. European and Canadian non-HVAC Electric and DHW 625 Load Profiles for Use in Simulating the Performance of Residential Cogeneration Systems, 626 IEA ECBCS Annex 42 Report, HMQR, Ottawa, Canada, ISBN 978-0-662-46221-7.

627 McCracken D, 2011. Synthetic High Resolution Solar Data, MSc Thesis, University of 628 Strathclyde, Glasgow, UK.

629 Munkhammar J, Grahn P, Widén J, 2013. Quantifying self-consumption of on-site 630 photovoltaic power generation in households with electric vehicle home charging, Solar 631 Energy, Volume 97, Pages 208-216.

632 Nissan UK, 2014. Nissan Leaf Data Sheet:

633 http://www.nissan.co.uk/content/dam/services/gb/brochure/LEAF\%20Tech\%20Spec.pdf

634 Accessed 11/06/14

635 OFGEM, 2013. Feed in Tariff Update 14. Available at:

636 https://www.ofgem.gov.uk/publications-and-updates/feed-tariff-update-quarterly-report-

637 issue-14. Accessed on 12 December 2013.

638 Palmer J, Cooper I (eds.). 2012. Great Britain's Housing Energy Fact File. Department for 639 Energy and Climate Change Publication, London, UK. URN 11D/866.

640 Panoutsou C, Castillo A, 2011. Outlook on Market Segments for Biomass Uptake by 2020 in 641 the UK, Intelligent Energy Europe Report, Imperial College, Available at: 642 http://www.biomassfutures.eu/public_docs/final_deliverables/WP2/D2.3\%200utlook\%20on $643 \%$ 20Market\%20Segments\%20for\%20Biomass\%20Uptake\%20by\%202020\%20in\%20the\%20 644 UK.pdf Accessed on 10/06/2014.

645 Pudjianto D, Djapic P, Aunedi M, Gan CK, Strbac G, Huang S, Infield D, 2013. Smart 646 control for minimizing distribution network reinforcement cost due to electrification, Energy 647 Policy, Volume 52, Pages 76-84.

648 Razeghi G, Zhang L, Brown T, Samuelsen S, 2014. Impacts of plug-in hybrid electric 649 vehicles on a residential transformer using stochastic and empirical analysis, Journal of 650 Power Sources, Volume 252, Pages 277-285.

651 Richardson I, Thompson M, Infield D, Clifford C 2010. Domestic electricity use: A high652 resolution energy demand model. Energy and Buildings 4210) Pages 1878-1887.

653 Robinson A P, Blythe P T, Bell M C, Hübner Y, Hill G A, 2013. Analysis of electric vehicle 654 driver recharging demand profiles and subsequent impacts on the carbon content of electric 655 vehicle trips, Energy Policy, Volume 61, Pages 337-348.

656 Schneiders J, CEPHEUS - measurement results from more than 100 dwelling units in passive 657 houses, Proc. eceee 2003 Summer Study, Saint Raphael, France, Pages 341-352. 
658 Wilson I A G, Rennie A J R, Ding Y, Eames P C, Hall P, Kelly N J 2013. Historical daily 659 gas and electrical energy flows through Great Britain's transmission networks and the 660 decarbonisation of domestic heat. Energy Policy, 61, Pages 301-305. 
Table 8a Electrical demand data from the base case and Scenarios 1-16.

\begin{tabular}{|c|c|c|c|c|c|c|c|c|c|}
\hline Scenario & Base Case & 1 & 2 & 3 & 4 & 5 & 6 & 7 & 8 \\
\hline Elec. demand $(\mathrm{kWh})$ & 387.8 & 1106.1 & 1136.9 & 1081.2 & 1074.6 & 1137.6 & 1133.3 & 1124.1 & 1144.2 \\
\hline EV demand (kWh) & - & 395.8 & 426.4 & 379.8 & 365.0 & 443.4 & 426.4 & 408.8 & 425.9 \\
\hline $\begin{array}{ll}\begin{array}{l}\text { Appl. } \\
(\mathrm{kWh})\end{array} & \text { demand } \\
\end{array}$ & 463.7 & 463.7 & 463.7 & 463.7 & 463.7 & 463.7 & 463.7 & 463.7 & 463.7 \\
\hline $\begin{array}{l}\text { ASHP } \\
(\mathrm{kWh})\end{array} \quad$ demand & - & 279.8 & 273.9 & 273.9 & 271.6 & 269.7 & 269.7 & 269.1 & 269.1 \\
\hline PV output $(\mathrm{kWh})$ & 223.7 & 223.7 & 223.7 & 223.7 & 223.7 & 223.7 & 223.7 & 223.7 & 223.7 \\
\hline Elec. export (kWh) & 139.3 & 112.9 & 116.1 & 110.1 & 118.5 & 106.3 & 116.3 & 128.2 & 128.2 \\
\hline $\begin{array}{l}\text { Self-consumption } \\
\text { (kWh) }\end{array}$ & 84.4 & 110.8 & 107.6 & 113.6 & 105.2 & 117.4 & 107.4 & 95.5 & 95.5 \\
\hline $\mathrm{BOP}$ and losses $\mathrm{kWh}$ & 160.4 & 144.0 & 134.7 & 149.9 & 131.0 & 156.6 & 133.9 & 113.1 & 110.1 \\
\hline $\begin{array}{lll}\text { Abs } & \text { Peak } & \text { demand } \\
\mathrm{kW} & & \end{array}$ & $5.12 @ 7 \mathrm{~d} 19 \mathrm{~h} 41 \mathrm{~m}^{*}$ & $10.08 @ 4 \mathrm{~d} 7 \mathrm{~h} 46 \mathrm{~m}$ & 12.22@7d9h11m & $8.01 @ 47 \mathrm{~d} 19 \mathrm{~h} 26 \mathrm{~m}$ & $8.25 @ 4 \mathrm{~d} 8 \mathrm{~h} 11 \mathrm{~m}$ & $7.96 @ 42 \mathrm{~d} 1 \mathrm{~h} 6 \mathrm{~m}$ & $11.33 @ 42 \mathrm{~d} 1 \mathrm{~h} 6 \mathrm{~m}$ & $9.09 @ 12 \mathrm{~d} 1 \mathrm{~h} 1 \mathrm{~m}$ & $11.57 @ 16 \mathrm{~d} 1 \mathrm{~h} 16 \mathrm{~m}$ \\
\hline $\begin{array}{lr}\text { Ave Daily } & \text { Peak } \\
\text { Demand kW } & \\
\end{array}$ & 2.29 & 6.15 & 7.53 & 6.03 & 6.78 & 4.96 & 6.86 & 5.81 & 7.45 \\
\hline Max P export kW & $2.28 @ 45 \mathrm{~d} 11 \mathrm{~h} 51 \mathrm{~m}$ & $2.24 @ 45 \mathrm{~d} 11 \mathrm{~h} 51 \mathrm{~m}$ & $2.24 @ 45 \mathrm{~d} 11 \mathrm{~h} 51 \mathrm{~m}$ & $2.24 @ 45 \mathrm{~d} 11 \mathrm{~h} 51 \mathrm{~m}$ & $2.24 @ 45 \mathrm{~d} 11 \mathrm{~h} 51 \mathrm{~m}$ & $2.24 @ 45 \mathrm{~d} 11 \mathrm{~h} 51 \mathrm{~m}$ & $2.24 @ 45 \mathrm{~d} 11 \mathrm{~h} 51 \mathrm{~m}$ & $2.24 @ 45 \mathrm{~d} 11 \mathrm{~h} 51 \mathrm{~m}$ & $2.24 @ 45 \mathrm{~d} 11 \mathrm{~h} 51 \mathrm{~m}$ \\
\hline $\begin{array}{ll}\text { Ave Daily } & \text { Peak } \\
\text { Export kW } & \\
\end{array}$ & 1.0 & 0.95 & 0.93 & 0.96 & 0.93 & 0.96 & 0.93 & 0.96 & 0.96 \\
\hline Scenario & Base Case & 9 & 10 & 11 & 12 & 13 & 14 & 15 & 16 \\
\hline Elec. demand (kWh) & 387.8 & 1134.4 & 1150.5 & 1143.2 & 1153.0 & 1138.2 & 1157.3 & 1139.7 & 1153.2 \\
\hline EV demand (kWh) & - & 428.3 & 431.2 & 428.3 & 428.7 & 428.2 & 432.3 & 428.3 & 432.4 \\
\hline $\begin{array}{l}\text { Appl. } \quad \text { demand } \\
\text { (kWh) }\end{array}$ & 463.7 & 463.7 & 463.7 & 463.7 & 463.7 & 463.7 & 463.7 & 463.7 & 463.7 \\
\hline $\begin{array}{l}\text { ASHP } \\
(\mathrm{kWh})\end{array}$ & - & 277.7 & 279.0 & 286.4 & 286.1 & 281.3 & 283.3 & 283.3 & 281.5 \\
\hline PV output $(\mathrm{kWh})$ & 223.7 & 223.7 & 223.7 & 223.7 & 223.7 & 223.7 & 223.7 & 223.7 & 223.7 \\
\hline Elec. export (kWh) & 139.3 & 110.7 & 119.6 & 110.3 & 117.2 & 110.7 & 120.7 & 110.0 & 118.4 \\
\hline $\begin{array}{l}\text { Self-consumption } \\
(\mathrm{kWh})\end{array}$ & 84.4 & 113.0 & 104.1 & 113.4 & 106.5 & 113.0 & 103.0 & 113.7 & 105.3 \\
\hline BOP and losses kWh & 160.4 & 148.3 & 127.6 & 148.6 & 132.1 & 148.0 & 125.1 & 149.3 & 129.8 \\
\hline Max demand kW & $5.12 @ 7 \mathrm{~d} 19 \mathrm{~h} 41 \mathrm{~m}$ & $7.82 @ 27 \mathrm{~d} 12 \mathrm{~h} 51 \mathrm{~m}$ & $9.91 @ 14 \mathrm{~d} 16 \mathrm{~h} 11 \mathrm{~m}$ & $7.61 @ 47 \mathrm{~d} 19 \mathrm{~h} 16 \mathrm{~m}$ & $7.78 @ 47 \mathrm{~d} 19 \mathrm{~h} 21 \mathrm{~m}$ & $7.53 @ 27 \mathrm{~d} 12 \mathrm{~h} 51 \mathrm{~m}$ & 7.97@3d18h51m & 7.48@19d9h26m & 7.49@45d18h41m \\
\hline $\begin{array}{lll}\text { Ave } & \text { Daily } & \text { Peak } \\
\text { Import } \mathrm{kW} & \\
\end{array}$ & 2.29 & 5.57 & 7.07 & 5.71 & 6.55 & 5.54 & 6.78 & 5.47 & 6.42 \\
\hline Max Export kW & $2.28 @ 45 \mathrm{~d} 11 \mathrm{~h} 51 \mathrm{~m}$ & $2.24 @ 45 \mathrm{~d} 11 \mathrm{~h} 51 \mathrm{~m}$ & $2.24 @ 45 \mathrm{~d} 11 \mathrm{~h} 51 \mathrm{~m}$ & $2.24 @ 45 \mathrm{~d} 11 \mathrm{~h} 51 \mathrm{~m}$ & $2.24 @ 45 \mathrm{~d} 11 \mathrm{~h} 51 \mathrm{~m}$ & $2.24 @ 45 \mathrm{~d} 11 \mathrm{~h} 51 \mathrm{~m}$ & $2.24 @ 45 \mathrm{~d} 11 \mathrm{~h} 51 \mathrm{~m}$ & $2.24 @ 45 \mathrm{~d} 11 \mathrm{~h} 51 \mathrm{~m}$ & $2.24 @ 45 \mathrm{~d} 11 \mathrm{~h} 51 \mathrm{~m}$ \\
\hline $\begin{array}{ll}\text { Ave Daily } & \text { Peak } \\
\text { Export } \mathrm{kW} & \end{array}$ & 1.0 & 0.96 & 0.93 & 0.96 & 0.93 & 0.96 & 0.93 & 0.96 & 0.93 \\
\hline
\end{tabular}

*@44d1h6m-indicates occurrence on day 44 at 1:06am 
Table 8b EV performance data from the base case and Scenarios 1-8.

\begin{tabular}{|l|l|l|l|l|l|l|l|l|l|}
\hline Scenario & $\begin{array}{l}\text { Base } \\
\text { Case }\end{array}$ & $\mathbf{1}$ & $\mathbf{2}$ & $\mathbf{3}$ & $\mathbf{4}$ & $\mathbf{5}$ & $\mathbf{6}$ & $\mathbf{7}$ & $\mathbf{8}$ \\
\hline EV demand (kWh) & - & 395.8 & 426.4 & 379.8 & 365.0 & 443.4 & 426.4 & 408.8 & 425.9 \\
\hline Distance travelled (km) & - & 2388.4 & 2588.7 & 2292.4 & 2219.6 & 2673.5 & 2588.7 & 2547.2 & 2620.3 \\
\hline Return trips (-) & - & 107 & 112 & 111 & 109 & 112 & 112 & 103 & 105 \\
\hline Maximum charge time (mins) & - & 328 & 172 & 368 & 190 & 348 & 172 & 1156 & 998 \\
\hline Max. discharge-to-house time (mins) & - & - & - & - & - & - & - & - & - \\
\hline Number of discharges-to-house (-) & - & - & - & - & - & - & - & - & - \\
\hline Mean SOC (\%) & - & 97.1 & 98.3 & 96.8 & 99.0 & 96.0 & 98.3 & 74.1 & 78.2 \\
\hline Scenario & $\mathbf{B a s e}$ & $\mathbf{9}$ & $\mathbf{1 0}$ & $\mathbf{1 1}$ & $\mathbf{1 2}$ & $\mathbf{1 3}$ & $\mathbf{1 4}$ & $\mathbf{1 5}$ & $\mathbf{1 6}$ \\
\hline EV demand (kWh) & - & 428.3 & 431.2 & 428.3 & 428.7 & 428.2 & 432.3 & 428.3 & 432.4 \\
\hline Distance travelled (km) & - & 2583.3 & 2615.8 & 2583.3 & 2598.7 & 2583.3 & 2621.0 & 2583.3 & 2621.0 \\
\hline Return trips (-) & - & 106 & 102 & 106 & 102 & 106 & 101 & 106 & 101 \\
\hline Maximum charge time (mins) & - & 387.0 & 193.0 & 387.0 & 248.0 & 387.0 & 214.0 & 392.0 & 249.0 \\
\hline Max. discharge-to-house time (mins) & - & - & - & 6 & 10 & - & - & 0 & 1 \\
\hline Number of discharges-to-house (-) & - & - & - & 1 & 1 & - & - & 0 & 1 \\
\hline Mean SOC (\%) & - & 95.7 & 98.2 & 95.6 & 97.8 & 95.7 & 98.1 & 95.7 & 97.9 \\
\hline
\end{tabular}


Table 8c Heating performance data from the base case and Scenarios 1-8.

\begin{tabular}{|c|c|c|c|c|c|c|c|c|c|}
\hline Scenario & $\begin{array}{l}\text { Base } \\
\text { Case } \\
\end{array}$ & 1 & 2 & 3 & 4 & 5 & 6 & 7 & 8 \\
\hline ASHP demand $(\mathrm{kWh})$ & - & 279.8 & 273.9 & 273.9 & 271.6 & 269.7 & 269.7 & 269.1 & 269.1 \\
\hline ASHP heat output (kWhrs) & - & 858.5 & 841.3 & 839.3 & 832.1 & 833.8 & 833.8 & 832.3 & 832.3 \\
\hline Mean air temp. occupied hours $\left({ }^{\circ} \mathrm{C}\right)$ & 21.4 & 21.3 & 21.4 & 21.3 & 21.3 & 21.2 & 21.2 & 21.2 & 21.2 \\
\hline$\%$ of time air temp $<18^{\circ} \mathrm{C}$ & 0.17 & 0.1 & 0.1 & 0.2 & 0.2 & 3.9 & 3.9 & 4.1 & 4.1 \\
\hline Mean hot water temp. hours $\left({ }^{\circ} \mathrm{C}\right)$ & 53.8 & 53.8 & 54.0 & 54.1 & 54.1 & 53.3 & 53.3 & 53.3 & 53.3 \\
\hline Scenario & $\begin{array}{l}\text { Base } \\
\text { Case } \\
\end{array}$ & 9 & 10 & 11 & 12 & 13 & 14 & 15 & 16 \\
\hline ASHP demand (kWh) & - & 277.7 & 279.0 & 286.4 & 286.1 & 281.3 & 283.3 & 283.3 & 281.5 \\
\hline ASHP heat output (kWhrs) & - & 853.1 & 856.8 & 867.7 & 868.1 & 854.9 & 865.0 & 859.8 & 862.1 \\
\hline Mean air temp. occupied hours $\left({ }^{\circ} \mathrm{C}\right)$ & 21.4 & 21.4 & 21.3 & 21.4 & 21.4 & 21.4 & 21.4 & 21.4 & 21.3 \\
\hline$\%$ of time air temp $<18^{\circ} \mathrm{C}$ & 0.17 & 0.2 & 0.2 & 0.6 & 0.6 & 0.5 & 0.7 & 0.8 & 0.4 \\
\hline Mean hot water temp. hours $\left({ }^{\circ} \mathrm{C}\right)$ & 53.8 & 54.0 & 53.9 & 54.1 & 54.0 & 54.0 & 54.0 & 54.1 & 53.9 \\
\hline
\end{tabular}




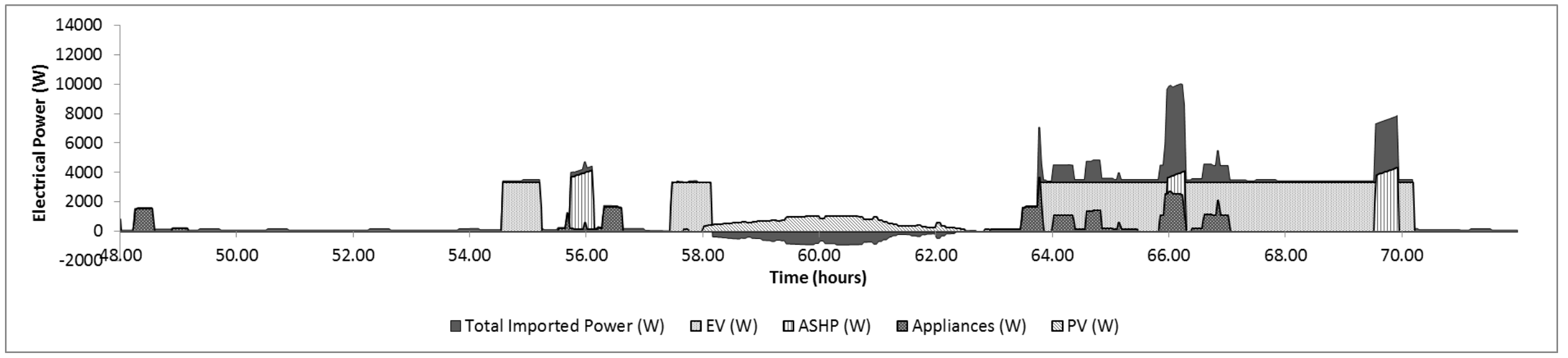

Figure 6a: typical daily profile of electrical supply and demand for unrestricted slow vehicle charging and heat pump operation.

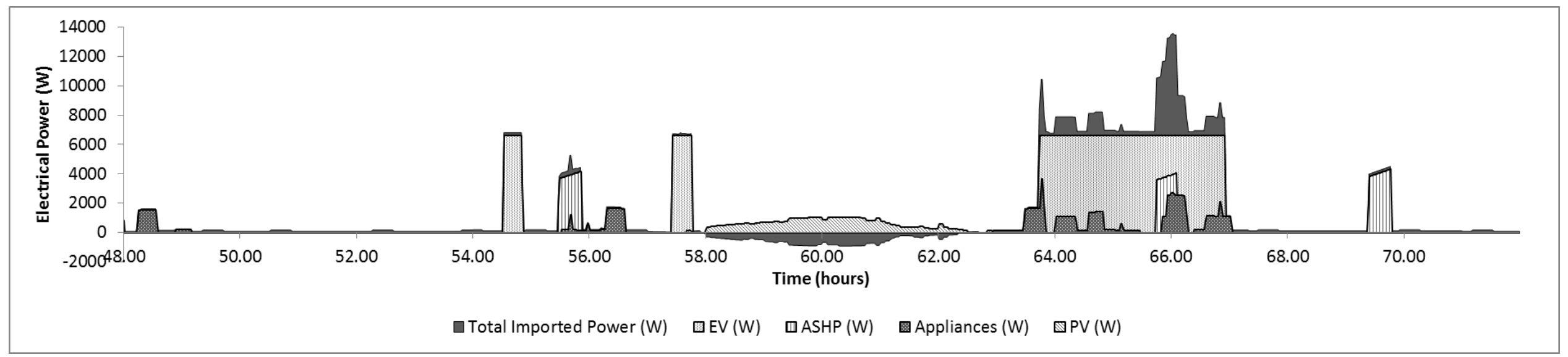

Figure 6b: typical daily profile of electrical supply and demand for unrestricted fast vehicle charging and heat pump operation. 


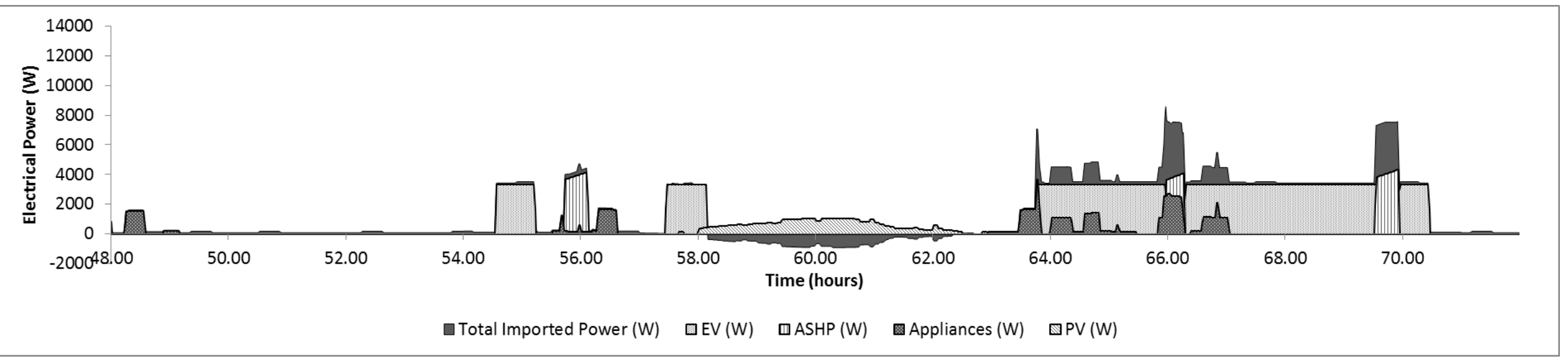

Figure 6c: typical daily profile of electrical supply and demand for load restricted slow vehicle charging and unrestricted heat pump operation.

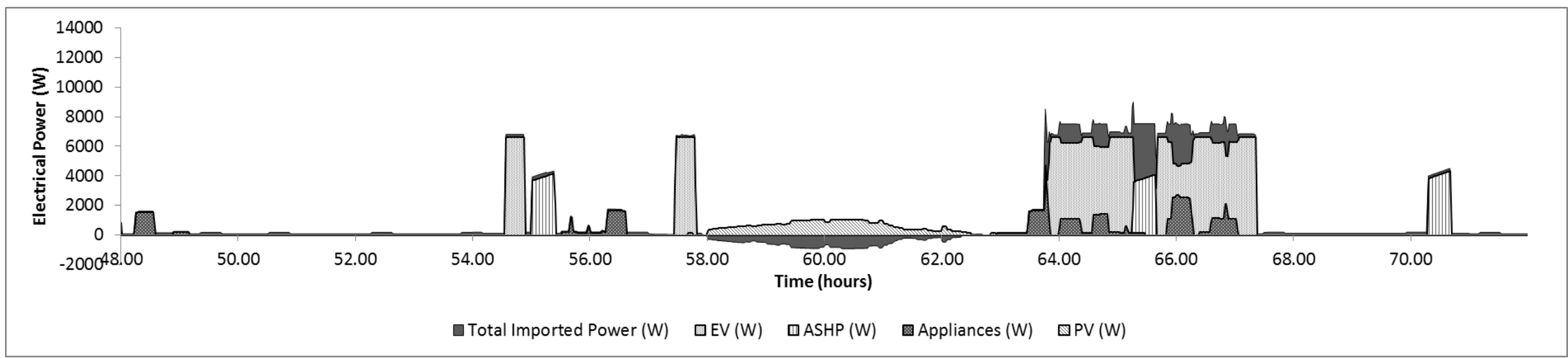

Figure 6d: typical daily profile of electrical supply and demand for load restricted fast vehicle charging and unrestricted heat pump operation. 


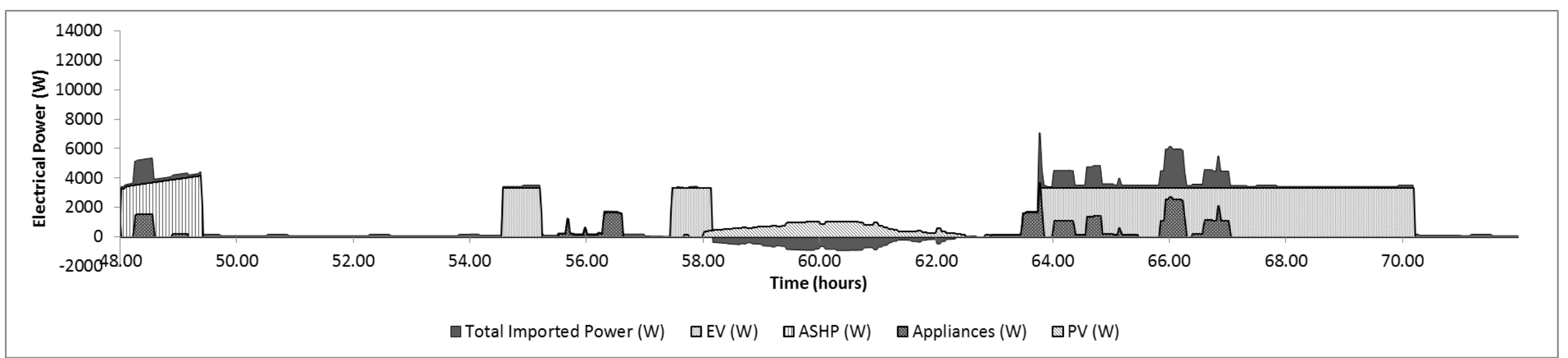

Figure 6e: typical daily profile of electrical supply and demand for unrestricted slow vehicle charging and off-peak heat pump operation.

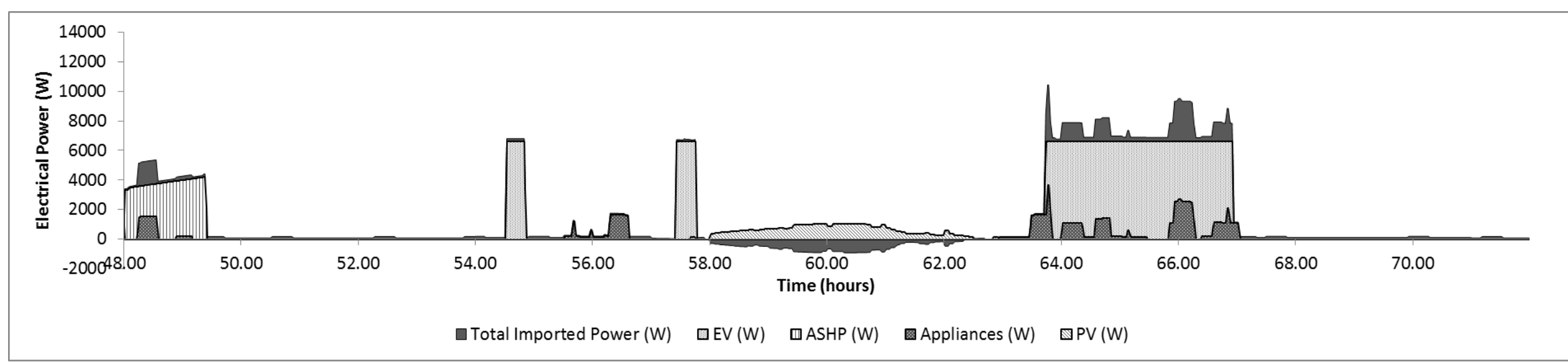

Figure 6f: typical daily profile of electrical supply and demand for unrestricted fast vehicle charging and off-peak heat pump operation. 


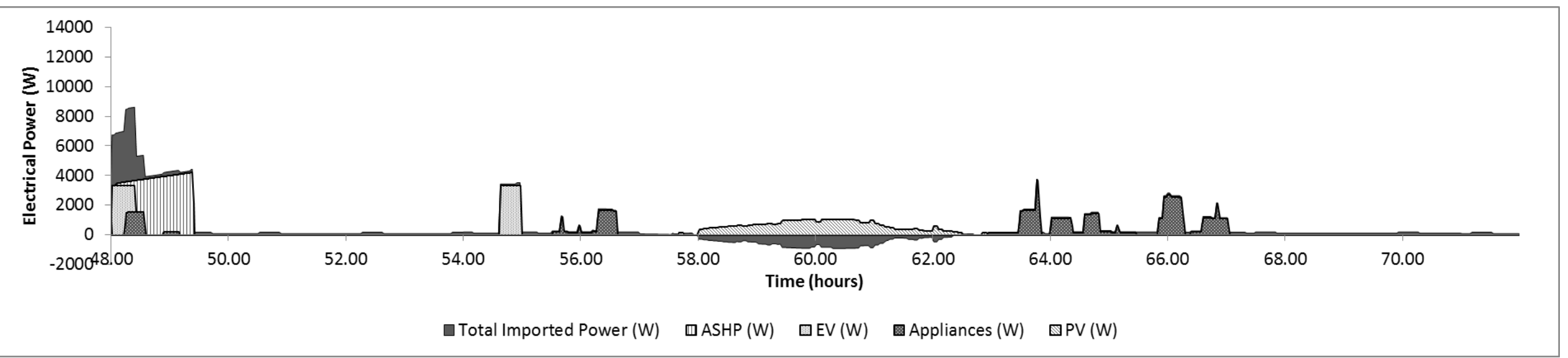

Figure 6g: typical daily profile of electrical supply and demand for off-peak slow vehicle charging and off-peak heat pump operation.

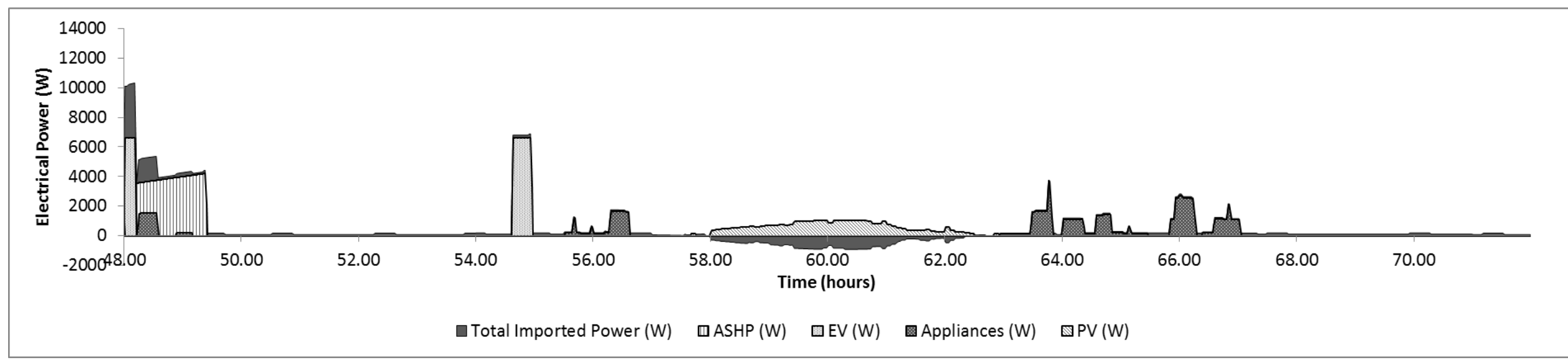

Figure 6h: typical daily profile of electrical supply and demand for off-peak fast vehicle charging and off-peak heat pump operation. 


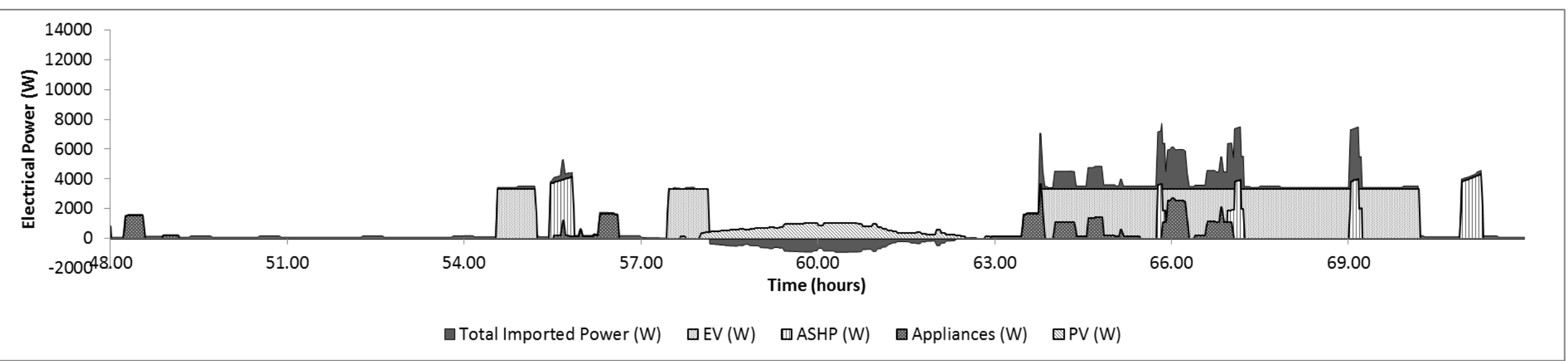

Figure 6i: typical daily profile of electrical supply and demand for restricted heat pump operation and unrestricted slow vehicle charging.

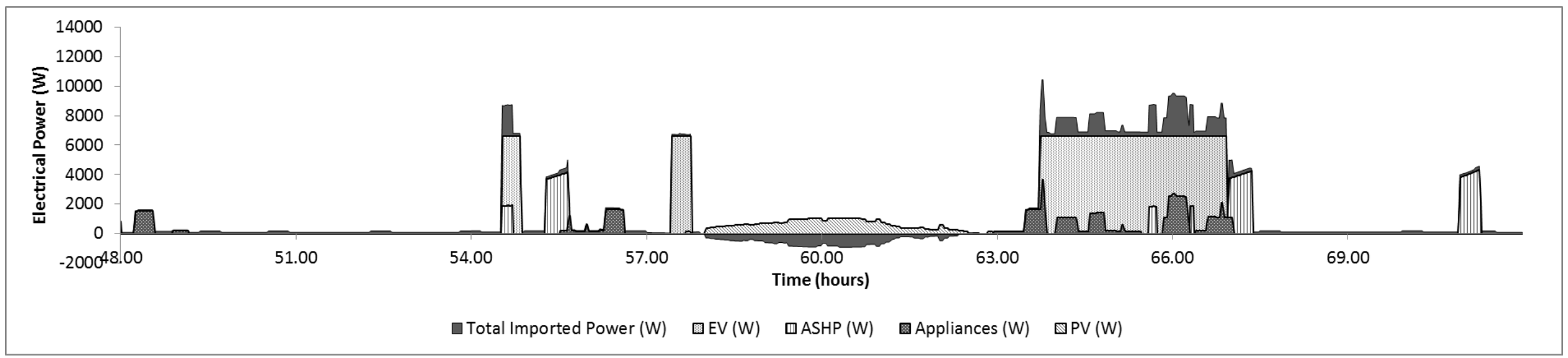

Figure 6j: typical daily profile of electrical supply and demand for restricted heat pump operation and unrestricted fast vehicle charging. 


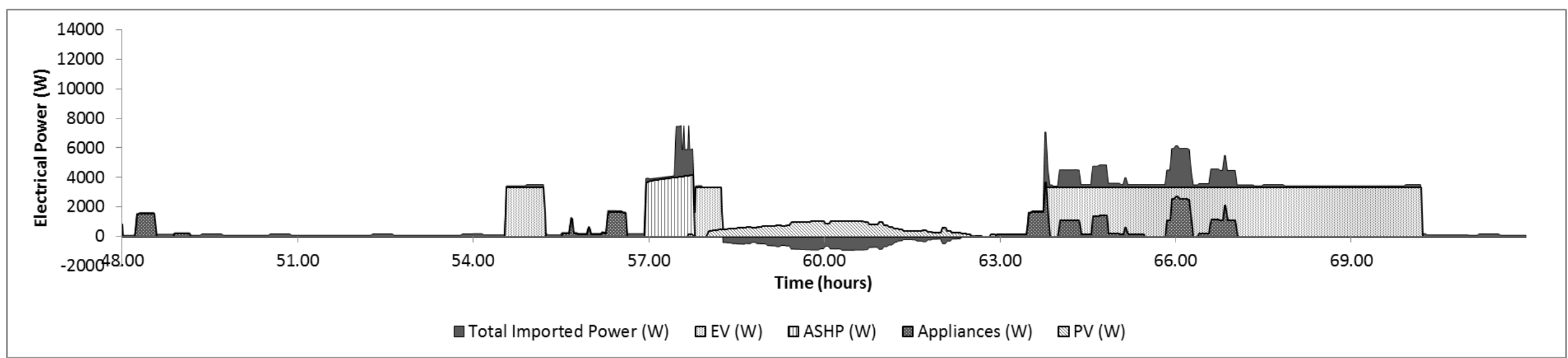

Figure 6k: typical daily profile of electrical supply and demand for unrestricted heat pump use and bi-directional slow battery operation.

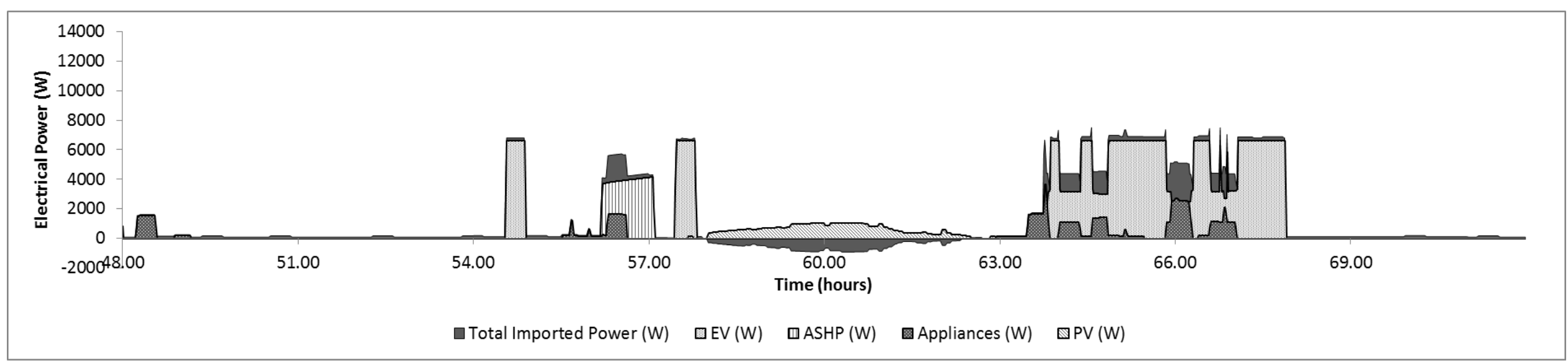

Figure 6l: typical daily profile of electrical supply and demand for unrestricted heat pump use and bi-directional fast battery operation. 


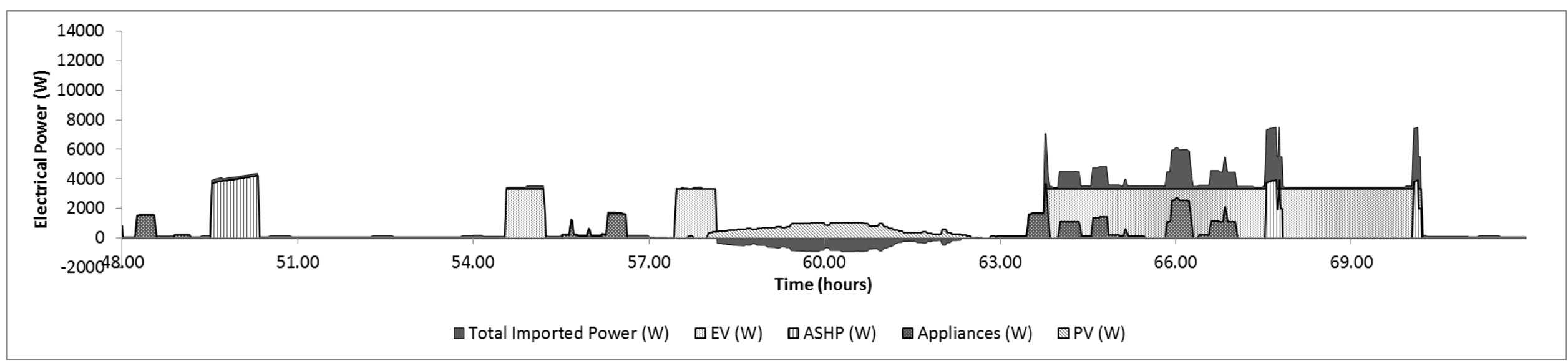

Figure 6m: typical daily profile of electrical supply and demand for demand restricted heat pump and slow battery charging.

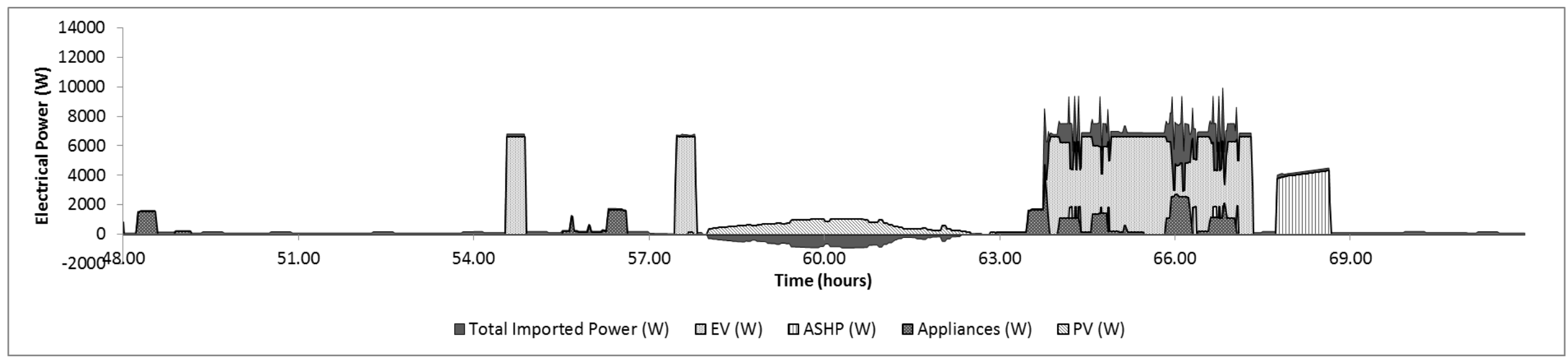

Figure 6n: typical daily profile of electrical supply and demand for demand restricted heat pump and fast battery charging. 


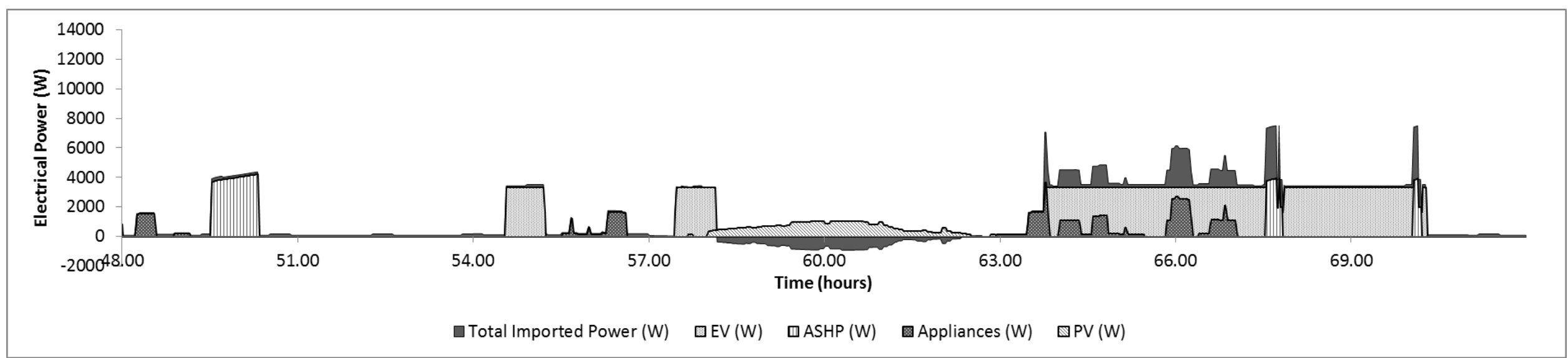

Figure 6o: typical daily profile of electrical supply and demand for demand restricted heat pump and bi-directional slow battery operation.

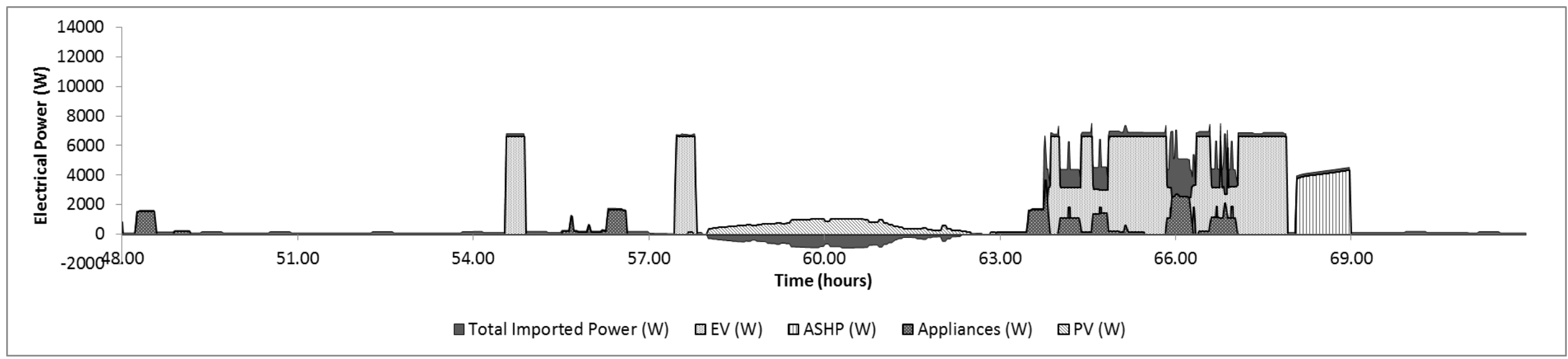

Figure 6p: typical daily profile of electrical supply and demand for demand restricted heat pump and bi-directional slow battery operation. 